\title{
Dinocyst Biostratigraphy of Tertiary Sediments from Five Cores from Screven and Burke Counties, Georgia
}

\author{
By Lucy E. Edwards
}

\section{U.S. GEOLOGICAL SURVEY PROFESSIONAL PAPER 1603-G}




\section{CONTENTS}

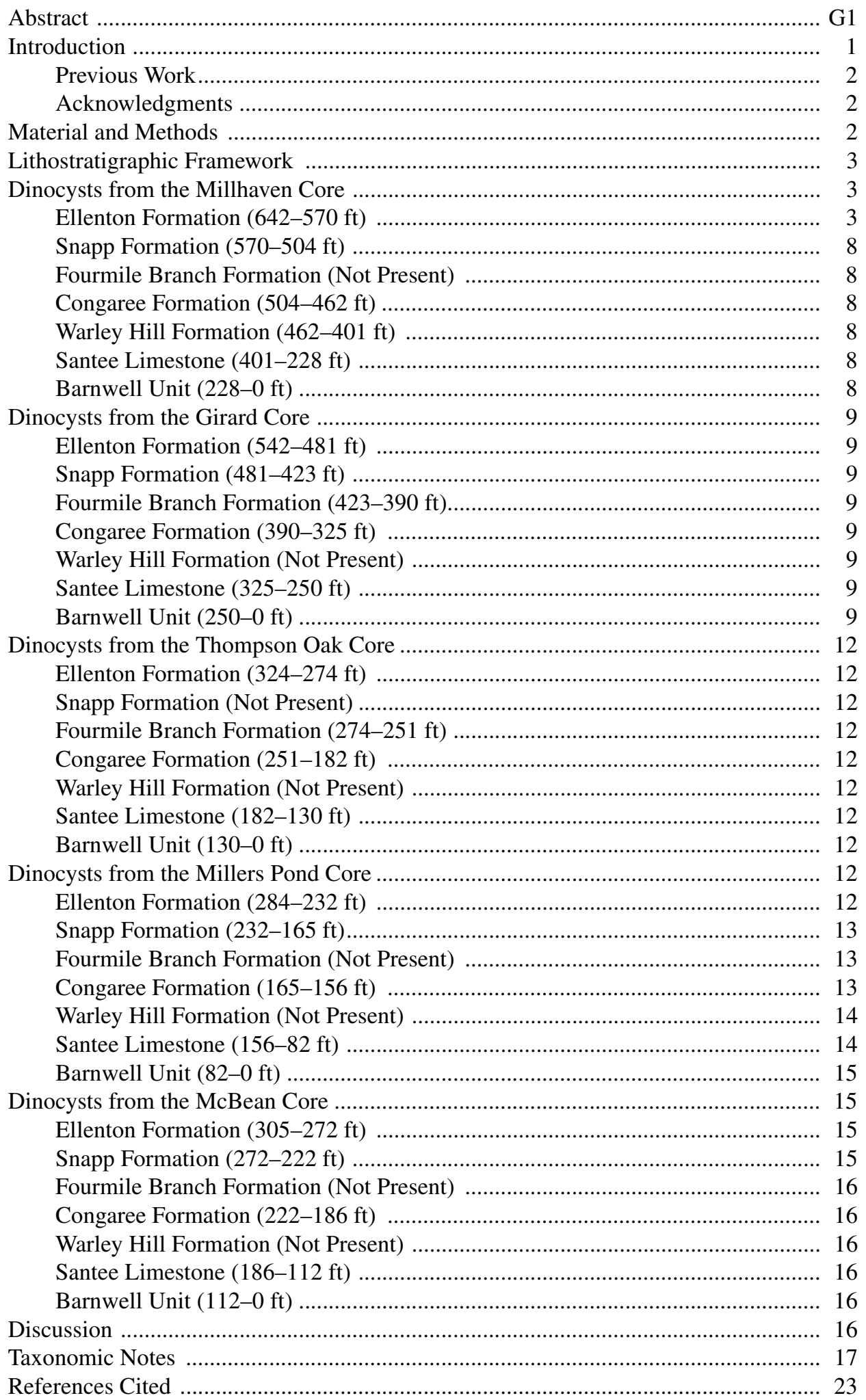




\section{PLATES}

[Plates follow References Cited]

1. Achilleodinium, Amphorosphaeridium, Areoligera, Areosphaeridium, Batiacasphaera, Carpatella, Cordosphaeridium, Cerebrocysta, Corrudinium, Cribroperidinium, and Dapsilidinium.

2. Damassadinium, Dinopterygium cladoides sensu Morgenroth (1966), Diphyes, Enneadocysta, Eocladopyxis, Fibradinium, Distatodinium, and Glaphyrocysta.

3. Hafniasphaera, Heteraulacacysta, Millioudodinium, Hystrichosphaeropsis, Homotryblium, Hystrichostrogylon, Operculodinium, and Pentadinium.

4. Pentadinium, Samlandia, Spiniferites, Systematophora, Tenua, Tectatodinium, Tuberculodinium, Turbiosphaera, and miscellaneous areoligeracean forms.

5. Andalusiella, Isabelidinium, Deflandrea, Dracodinium, Phelodinium, Charlesdowniea, Lentinia, Palaeoperidinium, Phthanoperidinium, and Selenopemphix.

6. Pseudorhombodinium, Rhombodinium, Selenopemphix, Senegalinium, Spinidinium, Wetzeliella, small peridiniacean forms, Cyclopsiella, and Xenikoon.

\section{FIGURES}

1. Index map showing the Savannah River Site and locations of stratigraphic test holes in the study area

2-6. Range and occurrence charts of dinocysts and acritarchs in the-

2. Millhaven core

3. Girard core

4. Thompson Oak core

5. Millers Pond core

6. McBean core

7. Correlation diagram by dinocyst assemblages for the five Georgia cores

\section{TABLES}

1. Samples studied by core with U.S. Geological Survey paleobotanical numbers (R numbers), depth below surface, and geologic unit.

2. Slide numbers and microscope coordinates of photographed specimens 


\title{
Dinocyst Biostratigraphy of Tertiary Sediments from Five Cores from Screven and Burke Counties, Georgia
}

\author{
By Lucy E. Edwards
}

\begin{abstract}
Dinoflagellate cysts and acritarchs from five cores in Burke and Screven Counties in Georgia reveal a complex pattern of deposition and erosion. Paleocene sediments in the Ellenton Formation include two separate assemblages. The older one is of early Paleocene age (Danian, Midwayan) and contains Carpatella cornuta Grigorovich; the younger assemblage contains Phelodinium sp. of Edwards (1989, U.S. Geological Survey Professional Paper 1489-C) and is of late Paleocene age (Selandian and Thanetian, Midwayan and Sabinian). Andalusiella sp. aff. A. polymorpha of Edwards (1980, Geological Society of America Field Trip Guidebooks, v. 2, p. 424-427) and Isabelidinium viborgense sensu Kurita and McIntyre (1995, Palynology, v. 19, p. 119 136) may be found just below and in the lower part of the upper assemblage.

The Snapp Formation is present in varying thicknesses in four of the five cores. Rare dinocysts are present but are not age diagnostic. The Fourmile Branch Formation is early Eocene and is recognized only in the Thompson Oak core where the Snapp Formation is absent and in the Girard core. Early Eocene dinocysts are conspicuously missing from the Millhaven, Millers Pond, and McBean cores.

Lower middle Eocene sediments of the Congaree Formation containing Pentadinium favatum Edwards are present in all cores. The highest occurrence of Turbiosphaera cf. T. galatea and the lowest occurrence of Glaphyrocysta $\mathrm{cf}$. G.? vicina may mark an important level near the calcareous nannofossil Zone NP 14/NP 15 boundary. Sediments containing both P. favatum Edwards and Pentadinium goniferum Edwards are found only in the Millhaven core, where they are assigned to calcareous nannofossil Zone NP 15 and to the Warley Hill Formation.

Upper middle Eocene sediments are present in the Santee Limestone in all cores. The lowest occurrences of Cordosphaeridium cantharellus (Brosius) Gocht, Cyclopsiella vieta Drugg \& Loeblich, and Dapsilidinium
\end{abstract}

pseudocolligerum (Stover) Bujak et al. are found in the Santee Limestone, and Hystrichosphaeropsis Deflandre n. sp. A, Pentadinium Gerlach n. sp. D, and Pentadinium polypodum Edwards are apparently restricted to the Santee Limestone. Specimens of species of the genus Wetzeliella are present in a few Santee samples but are not common.

Dinocyst recovery is variable in sediments of the Barnwell unit. In the Millhaven core, Batiacasphaera baculata Drugg, Batiacasphaera compta Drugg, and Cordosphaeridium funiculatum Morgenroth indicate a late Eocene age.

Core-to-core correlations based on the dinocyst assemblages show striking variations in units and thicknesses. The oldest Paleocene sediments are thickest in the updip direction. Of the five cores studied, none contains all three of the Fourmile Branch, Congaree, and Warley Hill Formations. Erosion by a paleo-Savannah River may have allowed selective infilling during later transgressions and selective preservation of the stratigraphic units.

\section{INTRODUCTION}

The Savannah River Site (SRS) in Aiken, Barnwell, and Allendale Counties, S.C., has manufactured, disposed of, and stored a variety of hazardous materials since the early 1950's. The U.S. Geological Survey, in cooperation with the U.S. Department of Energy and the Georgia Geologic Survey of the Georgia Department of Natural Resources, is conducting a study of the subsurface geology, hydrology, and water quality in the vicinity of the SRS. The goal of the study is to understand the actual and possible future ground-water flow in the aquifers of the area. This paper focuses on the Tertiary dinocyst biostratigraphy in Burke and Screven Counties in Georgia, directly across the Savannah River from the SRS (fig. 1).

Dinoflagellates are microscopic algae with a complex life cycle that may include an encysted stage. Chemically resistant dinoflagellate cysts (dinocysts) are abundant and well-preserved fossils in many of the Tertiary sediments in 


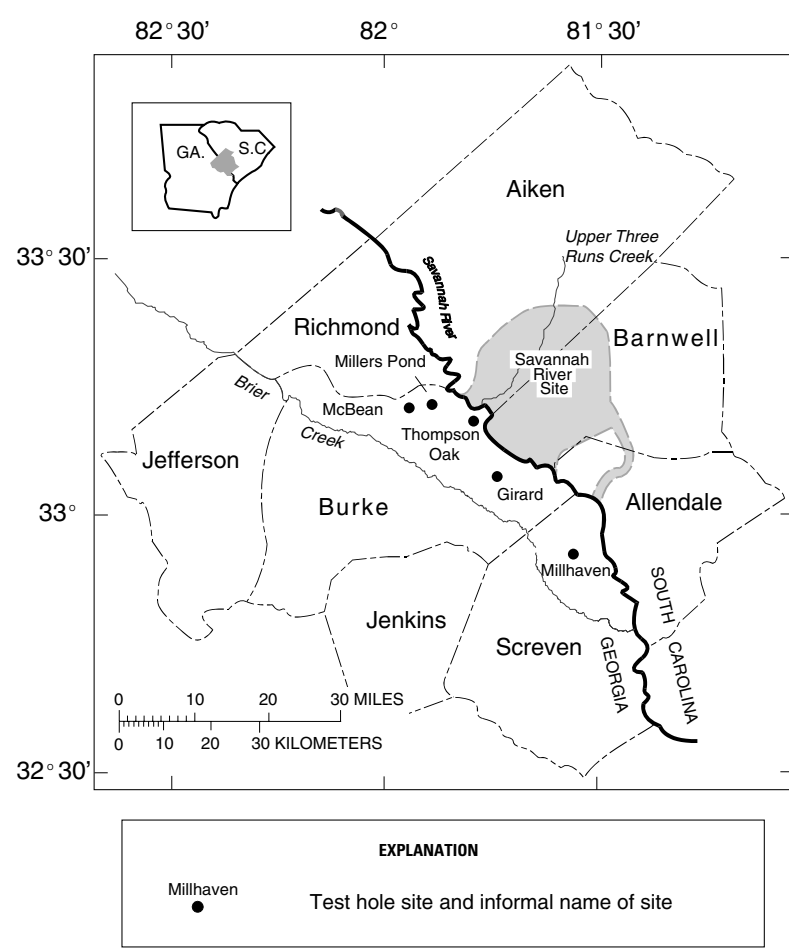

Figure 1. Index map showing the Savannah River Site and locations of stratigraphic test holes in the study area.

Burke and Screven Counties in Georgia. These rapidly evolving and distinctive fossils produce a detailed biostratigraphic framework for the area. Two distinctive, chemically resistant microfossils of uncertain origin (acritarchs) are also included in this study.

\section{PREVIOUS WORK}

Relatively little has been published on the dinoflagellate biostratigraphy of the southeastern United States. Early taxonomic works by Drugg and Loeblich (1967) and Drugg (1970) laid the foundation for later studies. Much of the biostratigraphic information used for correlation with classic Alabama localities is contained in Edwards (1977), and key species were named and documented in Edwards (1982). A preliminary report on the biostratigraphy of the Chattahoochee area in Alabama and Georgia was given in Edwards (1980). Prowell, Christopher, and others (1985) and Prowell, Edwards, and Frederiksen (1985) used dinocysts to help correlate units in the subsurface of Georgia and South Carolina and to help document the ages of stratigraphic units. Firth (1987) documented the dinocyst stratigraphy across the Cretaceous/Tertiary boundary in western Georgia.

More recently, brief papers by Edwards (1992) and Lucas-Clark (1992) have focused on the dinocysts of the
SRS and surrounding areas. Clarke and others $(1994,1996)$ and Leeth and others (1996) described the geologic and hydrologic data from three of the cores that are used in the present study. Recent papers by Kurita and McIntyre (1995) on the Paleocene of Manitoba, Canada, and by Edwards (1996) on the Eocene of Virginia and Maryland, U.S., show many forms similar to those encountered here.

\section{ACKNOWLEDGMENTS}

I thank U.S. Geological Survey colleagues Joan S. Baum, Laurel M. Bybell, John S. Clarke, W. Fred Falls, R. Farley Fleming, Norman O. Frederiksen, Thomas G. Gibson, Gregory S. Gohn, and David C. Prowell, as well as Raymond A. Christopher (Clemson University), Paul F. Huddlestun (Georgia Geologic Survey, Atlanta), Joyce Lucas-Clark (Fremont, Calif.), and Robert Van Pelt (Bechtel Savannah River) for the generous sharing of data and ideas concerning the biostratigraphy and lithostratigraphy of the coastal plain. Paul Huddlestun provided the samples from the Thompson Oak and McBean cores.

\section{MATERIAL AND METHODS}

This study is based on the dinocysts from five cores in east-central Georgia (fig. 1). They are discussed in order from most basinward (downdip) to most inshore (updip):

- The Millhaven test hole (33X048) was drilled by the U.S. Geological Survey in 1991-92 in northern Screven County at lat $32^{\circ} 53^{\prime} 25^{\prime \prime}$ N., long $81^{\circ} 35^{\prime} 43^{\prime \prime}$ W. Surface elevation is $110 \mathrm{ft}$ above sea level.

- The Girard test hole (32Y020) was drilled by the U.S. Geological Survey in 1992 in southern Burke County at the lookout tower on Griffins Landing Road. The test hole is located 2 miles north of the town of Girard at lat $33^{\circ} 03^{\prime} 54^{\prime \prime}$ N., long $81^{\circ} 43^{\prime} 13^{\prime \prime}$ W. Surface elevation is $250 \mathrm{ft}$ above sea level.

- The Thompson Oak test hole (GGS-3794, TR92-6, Burke 12) was drilled by the Georgia Geologic Survey in 1993 in northeastern Burke County. The test hole is located 21 miles south of Augusta just above the flood plain of the Savannah River at lat $33^{\circ} 10^{\prime} 42^{\prime \prime}$ N., long $81^{\circ} 47^{\prime} 10^{\prime \prime} \mathrm{W}$. Surface elevation is $240 \mathrm{ft}$ above sea level.

- The Millers Pond test hole (GGS-3758, Burke 2) was drilled by the Georgia Geologic Survey in 1991 in northern Burke County. The test hole is located 2 miles west of the Savannah River and 16 miles south of Augusta, at lat $33^{\circ} 13^{\prime} 48^{\prime \prime}$ N., long 81 ${ }^{\circ} 52^{\prime} 44^{\prime \prime}$ W. Surface elevation is $245 \mathrm{ft}$ above sea level.

- The McBean test hole (GGS-3757, Burke 5) was drilled by the Georgia Geologic Survey in 1991 in northern Burke County. The test hole is located on the north shoulder of Collins Road, 1.1 miles east of 
the intersection of GA 56 and Collins Road at lat $33^{\circ} 13^{\prime} 38^{\prime \prime}$ N., long $81^{\circ} 55^{\prime} 50^{\prime \prime}$ W. Surface elevation is $297 \mathrm{ft}$ above sea level.

Core samples were selected on the basis of favorable lithology and providing biostratigraphic coverage. Samples were assigned U.S. Geological Survey paleobotanical numbers by locality and letter designations by depth. Table 1 provides a convenient summary of these. The depth range includes the thickness of the sample as well as the uncertainty of the core recovery; sample depths recorded only to the nearest foot have a least $1 \mathrm{ft}$ of uncertainty in recovery.

Samples were cleaned and scraped and treated with hydrochloric and hydrofluoric acids. The samples were oxidized using nitric acid, stained with Bismark brown, sieved at 20 micrometers, and mounted in glycerin jelly for light-microscope observation. All slides are stored at the U.S. Geological Survey, Reston, Va.

Coordinates for dinoflagellate specimens are given for Olympus Vanox microscope 201526 at the U.S. Geological Survey, Reston, Va. On this microscope, the coordinates for the center point of a standard $25.4 \times 76.2$-millimeter slide are 27.5 and 112.7 for the vertical and horizontal axes. The vertical coordinates increase as the stage is moved up, and the horizontal coordinates increase as the slide is moved from left to right. Slide numbers and microscope coordinates of photographed specimens are listed in table 2.

Taxonomy follows Williams and others (1998). Full taxonomic citations for all forms in the text and figures are found in "Taxonomic Notes." In contrast to Williams and others (1998), however, I do not recognize the genus Tityrosphaeridium Sarjeant as separate and distinct from the genus Cordosphaeridium Eisenack, because both appear to possess cingular processes. Except for the distinctive species that are listed separately, the highly variable plexus that contains members of the genera Adnatosphaeridium, Areoligera, and Glaphyrocysta was considered to be a single taxonomic entity (miscellaneous areoligeraceae, pl. 4, figs. 13, 14).

\section{LITHOSTRATIGRAPHIC FRAMEWORK}

Details of the lithostratigraphy are given by Falls and Prowell (this volume, chap. A). They recognize seven Tertiary units, and their terminology and correlations are followed here. However, the individual components of their "Fourmile Branch/Congaree/Warley Hill unit" are discussed separately. The Ellenton Formation is the lowest Tertiary unit and consists of calcareous and noncalcareous sand and clay that is locally glauconitic. It is overlain by the Snapp Formation, a distinctive unlithified sand and overlying white kaolin. The Fourmile Branch Formation is recognized only in the Girard and Thompson Oak cores, where it consists of layers of clay and poorly sorted sand. The Congaree Formation consists of interbedded sand, marl, and limestone in downdip cores and sand with or without sandy carbonate in more updip cores. The Warley Hill Formation is found only in the Millhaven core and is primarily a carbonate sand. The Santee Limestone is predominantly a carbonate that includes beds of calcareous sand and clay. The Barnwell unit is a mixed lithologic package of sandy limestone, marl, clay, and sand. The Ellenton and Snapp Formations are Paleocene; the Fourmile Branch Formation, Congaree Formation, Warley Hill Formation, Santee Limestone, and Barnwell unit are Eocene (Edwards and others, this volume, chap. B).

\section{DINOCYSTS FROM THE MILLHAVEN CORE}

Thirty-three samples were examined for dinocysts in the Tertiary sediments in the Millhaven core, and all but six contained dinocysts. The occurrences of dinocyst taxa in this core are shown in figure 2.

\section{ELLENTON FORMATION (642-570 ft)}

Dinocysts in the Paleocene Ellenton Formation in the Millhaven core were studied from eight samples from 639.5-571 ft depth (table 1). The lowest sample (R4664 GC, at $639.5 \mathrm{ft}$ ) contains Areoligera volata Drugg, Carpatella cornuta Grigorovich (pl. 1, fig. 10), Spinidinium densispinatum Stanley, Spinidinium pulchrum (Benson) Lentin \& Williams, and Tenua sp. cf. T. formosa of Kurita and McIntyre (1995). Carpatella cornuta Grigorovich has not been reported from sediments younger than early Paleocene (Danian). Ellenton samples below $635.4 \mathrm{ft}$ have been assigned to calcareous nannofossil Zone NP 4 (Bybell, this volume, chap. F). The early-late Paleocene boundary is within Zone NP 4 (Berggren and others, 1995); the presence of $C$. cornuta Grigorovich indicates that these sediments are from the early Paleocene part of the zone.

The next higher sample ( $\mathrm{R} 4664 \mathrm{CH}$, at $632-632.2 \mathrm{ft}$ ) is dominated by small peridiniaceans such as Senegalinium microgranulatum (Stanley) Stover \& Evitt and contains other forms such as Palaeoperidinium pyrophorum (Ehrenberg) Sarjeant and Hafniasphaera septata (Cookson \& Eisenack) Hansen, Andalusiella sp. aff. A. polymorpha of Edwards (1980), and Deflandrea cf. D. diebelii of Drugg (1967). The remaining Ellenton samples contain similar assemblages that include Damassadinium californicum (Drugg) Fensome et al. (pl. 2, fig. 3), Phelodinium sp. of Edwards (1989) (lowest occurrence in R4664 GD, at 620.8 $\mathrm{ft}$ ), and Deflandrea delineata Cookson \& Eisenack (lowest occurrence in R4664 A, at $589 \mathrm{ft}, \mathrm{pl} .5,5.5)$. Palaeoperidinium pyrophorum (Ehrenberg) Sarjeant and Fibradinium annetorpense Morgenroth are present in the highest sample (R4664 D, at $571 \mathrm{ft}$ ). Most of the Ellenton has been 
Table 1. Samples studied by core with U.S. Geological Survey paleobotanical numbers (R numbers), depth below surface, and geologic unit.

[Fourmile, Fourmile Branch Formation; T/F, discussed in text and figures]

\begin{tabular}{|c|c|c|c|c|c|c|c|}
\hline $\mathrm{R}$ number & Depth (ft) & Unit & Notes & R number & Depth (ft) & Unit & Notes \\
\hline \multicolumn{4}{|c|}{ Millhaven core } & \multicolumn{4}{|c|}{ Girard core-Continued } \\
\hline R4664 AV ----- & 105 & Barnwell & Barren. & R4705 E ------ & $362-362.3$ & Congaree & $\mathrm{T} / \mathrm{F}$ \\
\hline R4664 AU ----- & 118 & Barnwell & 1 dinocyst. & R4705 CF ----- & 415 & Fourmile & $\mathrm{T} / \mathrm{F}$ \\
\hline R4664 AT------ & 195 & Barnwell & 1 dinocyst. & R4705 AE ----- & $415.2-415.5$ & Fourmile & $\mathrm{T} / \mathrm{F}$ \\
\hline R4664 AS ----- & 205 & Barnwell & $\mathrm{T} / \mathrm{F}$ & R4705 D------- & $484.1-484.3$ & Ellenton & $\mathrm{T} / \mathrm{F}$ \\
\hline R4664 AR ----- & 210 & Barnwell & $\mathrm{T} / \mathrm{F}$ & R4705 C ------- & $514-514.3$ & Ellenton & $\mathrm{T} / \mathrm{F}$ \\
\hline R4664 AQ ----- & 216.5 & Barnwell & $\mathrm{T} / \mathrm{F}$ & R4705 AD----- & $517.9-518.1$ & Ellenton & $\mathrm{T} / \mathrm{F}$ \\
\hline R4664 AP ----- & 227.5 & Barnwell & $\mathrm{T} / \mathrm{F}$ & R4705 B ------- & $521-521.2$ & Ellenton & $\mathrm{T} / \mathrm{F}$ \\
\hline R4664 AO ----- & 237.5 & Santee & Barren. & R4705 A------- & $532.5-532.7$ & Ellenton & $\mathrm{T} / \mathrm{F}$ \\
\hline R4664 AN----- & 242.5 & Santee & Barren. & \multicolumn{4}{|c|}{ Thompson Oak core } \\
\hline R4664 AL ----- & 260 & Santee & Barren. & R4836 R ------- & 138 & Santee & $\mathrm{T} / \mathrm{F}$ \\
\hline R4664 AI ------ & 293 & Santee & $\mathrm{T} / \mathrm{F}$ & R4836 Q------- & 154 & Santee & $\mathrm{T} / \mathrm{F}$ \\
\hline R4664 AG ----- & 313.5 & Santee & $\mathrm{T} / \mathrm{F}$ & R4836 P ------- & 164 & Santee & $\mathrm{T} / \mathrm{F}$ \\
\hline R4664 AC ----- & 346 & Santee & $\mathrm{T} / \mathrm{F}$ & R4836 O------- & 172 & Santee & $\mathrm{T} / \mathrm{F}$ \\
\hline R4664 Y ------- & 375 & Santee & $\mathrm{T} / \mathrm{F}$ & R4836 N------- & 174 & Santee & $\mathrm{T} / \mathrm{F}$ \\
\hline R4664 X ------- & 396 & Santee & Barren. & R4836 M ------ & 181.5 & Santee & $\mathrm{T} / \mathrm{F}$ \\
\hline R4664 V ------- & 413 & Warley Hill & $\mathrm{T} / \mathrm{F}$ & R4836 L ------- & 183 & Congaree & $\mathrm{T} / \mathrm{F}$ \\
\hline R4664 R ------- & 442 & Warley Hill & $\mathrm{T} / \mathrm{F}$ & R4836 K------- & 192 & Congaree & $\mathrm{T} / \mathrm{F}$ \\
\hline R4664 O ------- & 466 & Congaree & $\mathrm{T} / \mathrm{F}$ & R4836 J -------- & 194 & Congaree & $\mathrm{T} / \mathrm{F}$ \\
\hline R4664 N ------- & 473.5 & Congaree & $\mathrm{T} / \mathrm{F}$ & R4836 I -------- & 210 & Congaree & $\mathrm{T} / \mathrm{F}$ \\
\hline R4664 L ------- & 483.5 & Congaree & $\mathrm{T} / \mathrm{F}$ & R4836 H ------- & 231.5 & Congaree & $\mathrm{T} / \mathrm{F}$ \\
\hline R4664 K ------- & 490 & Congaree & $\mathrm{T} / \mathrm{F}$ & R4836 G ------- & 245 & Congaree & $\mathrm{T} / \mathrm{F}$ \\
\hline R4664 J -------- & 495.5 & Congaree & $\mathrm{T} / \mathrm{F}$ & R4836 F ------- & 255 & Fourmile & $\mathrm{T} / \mathrm{F}$ \\
\hline R4664 I -------- & 498.5 & Congaree & $\mathrm{T} / \mathrm{F}$ & R4836 E ------- & 269 & Fourmile & $\mathrm{T} / \mathrm{F}$ \\
\hline R4664 F ------- & 527 & Snapp & Barren. & R4836 D ------- & 281 & Ellenton & $\mathrm{T} / \mathrm{F}$ \\
\hline R4664 E ------- & $564-565$ & Snapp & $\mathrm{T} / \mathrm{F}$ & R4836 C ------- & 302 & Ellenton & $\mathrm{T} / \mathrm{F}$ \\
\hline R4664 D ------- & 571 & Ellenton & $\mathrm{T} / \mathrm{F}$ & \multicolumn{4}{|c|}{ Millers Pond core } \\
\hline R4664 C ------- & 577 & Ellenton & $\mathrm{T} / \mathrm{F}$ & R4581 Y ------- & $72-77$ & Barnwell & Barren. \\
\hline R4664 B ------- & 581 & Ellenton & $\mathrm{T} / \mathrm{F}$ & R4581 X------- & $82-83$ & Santee & Barren. \\
\hline R4664 A ------- & 589 & Ellenton & $\mathrm{T} / \mathrm{F}$ & R4581 W ------ & 120 & Santee & $\mathrm{T} / \mathrm{F}$ \\
\hline R4664 GE ----- & 599.5 & Ellenton & $\mathrm{T} / \mathrm{F}$ & R4581 V ------- & 124 & Santee & $\mathrm{T} / \mathrm{F}$ \\
\hline R4664 GD ----- & 620.8 & Ellenton & $\mathrm{T} / \mathrm{F}$ & R4581 U ------- & 148 & Santee & $\mathrm{T} / \mathrm{F}$ \\
\hline R4664 CH ----- & $632-632.2$ & Ellenton & $\mathrm{T} / \mathrm{F}$ & R4581 T ------- & 155 & Santee & $\mathrm{T} / \mathrm{F}$ \\
\hline R4664 GC ----- & 639.5 & Ellenton & $\mathrm{T} / \mathrm{F}$ & R4581 S ------- & 165 & Congaree & $\mathrm{T} / \mathrm{F}$ \\
\hline \multicolumn{4}{|c|}{ Girard core } & R4581 R ------- & $237-242$ & Ellenton & $\mathrm{T} / \mathrm{F}$ \\
\hline$\overline{\mathrm{R} 4705 \mathrm{~L} \text {------- }}$ & $64.1-64.3$ & Barnwell & Barren. & R4581 Q------- & $252-257$ & Ellenton & $\mathrm{T} / \mathrm{F}$ \\
\hline R4705 K ------- & $103.6-103.8$ & Barnwell & Barren. & \multicolumn{4}{|c|}{ McBean core } \\
\hline R4705 J -------- & $146.6-146.8$ & Barnwell & $\mathrm{T} / \mathrm{F}$ & R4663 G------- & 181 & Santee & $\mathrm{T} / \mathrm{F}$ \\
\hline R4705 I -------- & $211.1-211.3$ & Barnwell & $\mathrm{T} / \mathrm{F}$ & R4663 F ------- & 210 & Congaree & $\mathrm{T} / \mathrm{F}$ \\
\hline R4705 H ------- & $257.8-258$ & Santee & $\mathrm{T} / \mathrm{F}$ & R4663 E ------- & 243 & Snapp & No dinocysts. \\
\hline R4705 G ------- & $321.4-321.6$ & Santee & $\mathrm{T} / \mathrm{F}$ & R4663 D------- & 264 & Snapp & $\mathrm{T} / \mathrm{F}$ \\
\hline R4705 F ------ & $322.3-322.5$ & Santee & $\mathrm{T} / \mathrm{F}$ & R4663 C ------ & 276 & Ellenton & $\mathrm{T} / \mathrm{F}$ \\
\hline R4705 AF ----- & $327.3-327.5$ & Congaree & $\mathrm{T} / \mathrm{F}$ & R4663 B ------- & 294 & Ellenton & $\mathrm{T} / \mathrm{F}$ \\
\hline
\end{tabular}


Table 2. Slide numbers and microscope coordinates of photographed specimens.

[The slide designations show the sample number (table 1) followed by the slide number in parentheses. Coordinates are given for Olympus Vanox microscope 201526 at the U.S. Geological Survey, Reston, Va.]

\begin{tabular}{|c|c|c|}
\hline Figure & Slide & Coordinates \\
\hline \multicolumn{3}{|c|}{ Plate 1} \\
\hline 1 1 ------------------- & R4664 K (1) & $31.1 \times 83.0$ \\
\hline 2 ---------------- & R4664 O (3) & $20.2 \times 93.2$ \\
\hline 3 ------------------- & R4705 E (2) & $33.5 \times 74.5$ \\
\hline 4 ----------------- & R4705 D (2) & $18.7 \times 80.3$ \\
\hline 5 ------------------- & R4581 Q (4) & $22.6 \times 81.2$ \\
\hline 6 ------------------- & R4664 R (4) & $27.6 \times 98.4$ \\
\hline 7 ----- & R4664 AS (1) & $30.7 \times 86.0$ \\
\hline 8, 9 --------------- & R4664 AS (1) & $30.2 \times 81.4$ \\
\hline 10 --------------- & R4664 GC (1) & $20.4 \times 97.0$ \\
\hline 11 ----------------- & R4664 AS (1) & $33.7 \times 78.6$ \\
\hline 12, 13 ------------- & R4664 K (1) & $28.2 \times 79.1$ \\
\hline 14 --------------- & R4664 AC (3) & $29.8 \times 81.4$ \\
\hline 15 ----------------- & R4705 I (3) & $35.6 \times 90.6$ \\
\hline 16 ---------------- & R4664 O (3) & $34.3 \times 89.4$ \\
\hline $17---$ & R4664 AC (3) & $27.3 \times 103.4$ \\
\hline 18 ----------------- & R4705 I (3) & $26.9 \times 94.4$ \\
\hline \multicolumn{3}{|c|}{ Plate 2} \\
\hline 1, 2 ---------------- & R4663 B (4) & $34.5 \times 93.8$ \\
\hline ------------- & R4664 A (3) & $22.1 \times 71.8$ \\
\hline 4 -------------------- & R4664 AS (1) & $30.9 \times 86.7$ \\
\hline 5 ---- & R4664 O (3) & $19.4 \times 103.8$ \\
\hline $6---$ & R4664 AQ (2) & $37.5 \times 80.7$ \\
\hline 7 ----- & R4705 E (2) & $21.1 \times 75.0$ \\
\hline 8 ----- & R4664 A (3) & $19.4 \times 97.7$ \\
\hline 9 -----------. & R4664 AR (1) & $37.2 \times 84.5$ \\
\hline 10-12------------ & R4664 O (3) & $34.3 \times 76.4$ \\
\hline 13 ----------------- & R4705 E (2) & $30.4 \times 75.6$ \\
\hline 14 ----------------- & R4836 K (3) & $26.0 \times 71.1$ \\
\hline 15 ---------------- & R4705 G (3) & $30.4 \times 89.0$ \\
\hline \multicolumn{3}{|c|}{ Plate 3} \\
\hline 1 ------------------- & R4836 F (2) & $30.0 \times 76.0$ \\
\hline 2, 3 --------------- & R4836 R (3) & $22.6 \times 79.6$ \\
\hline 4 ----- & R4663 G (3) & $33.2 \times 94.2$ \\
\hline ------------- & R4663 G (3) & $21.9 \times 77.1$ \\
\hline ------------- & R4664 AC (3) & $34.7 \times 84.7$ \\
\hline 7-9--------------- & R4836 R (3) & $17.8 \times 75.3$ \\
\hline 10 ---------------- & R4705 AD (2) & $26.9 \times 101.6$ \\
\hline 11 ----------------- & R4836 E (3) & $19.2 \times 89.6$ \\
\hline 12 ----------------- & R4705 I (3) & $28.9 \times 86.7$ \\
\hline 13 --------------- & R4836 N (4) & $35.0 \times 107.8$ \\
\hline 14 ----------------- & R4664 O (3) & $34.8 \times 85.1$ \\
\hline 15 ---------------- & R4664 N (2) & $30.8 \times 86.6$ \\
\hline 16 ----------------- & R4664 AC (3) & $35.7 \times 71.7$ \\
\hline 17 --------------- & R4664 AR (1) & $36.5 \times 101.9$ \\
\hline 18 ----------------- & R4664 AR (1) & $26.4 \times 94.9$ \\
\hline 19-21 ------------- & R4836 P (1) & $24.1 \times 108.0$ \\
\hline
\end{tabular}

\begin{tabular}{|c|c|c|}
\hline Figure & Slide & Coordinates \\
\hline \multicolumn{3}{|c|}{ Plate 4} \\
\hline 1 1 -------------------- & R4664 AI (4) & $33.3 \times 76.5$ \\
\hline 2 ---------------- & R4664 AI (4) & $21.4 \times 74.8$ \\
\hline 3 ------------------- & R4836 K (3) & $28.4 \times 97.0$ \\
\hline 4 ------------------- & R4664 AC (3) & $31.4 \times 103.8$ \\
\hline 5 ------------------- & R4664 AC (3) & $24.3 \times 72.3$ \\
\hline 6 ------------------ & R4705 I (3) & $24.0 \times 75.3$ \\
\hline 7 ------------------- & R4705 AD (2) & $33.7 \times 76.4$ \\
\hline 8 ------------------- & R4705 G (3) & $24.9 \times 90.4$ \\
\hline 9 --------------- & R4664 AR (1) & $35.7 \times 104.9$ \\
\hline 10, 11 ----------- & R4705 AD (2) & $33.6 \times 76.3$ \\
\hline 12---------------- & R4664 K (1) & $30.3 \times 78.0$ \\
\hline 13 ------------------ & R4664 K (1) & $31.9 \times 87.1$ \\
\hline 14----------------- & R4581 R (4) & $36.1 \times 91.1$ \\
\hline \multicolumn{3}{|c|}{ Plate 5} \\
\hline 1 -------------------- & R4581 R (1) & $23.2 \times 74.6$ \\
\hline 2 ------------------ & R4663 C (4) & $21.1 \times 93.5$ \\
\hline 3 --------------- & R4581 R (1) & $26.0 \times 73.0$ \\
\hline 4 -------------------- & R4836 D (3) & $22.4 \times 75.2$ \\
\hline $5---$ & R4664 A (3) & $23.5 \times 92.3$ \\
\hline $6----$ & R4705 AD (2) & $27.2 \times 95.5$ \\
\hline 7 ----- & R4705 CF (1) & $32.6 \times 72.4$ \\
\hline 8 ----- & R4705 B (3) & $30.5 \times 107.9$ \\
\hline 9 -----. & R4664 AS (1) & $24.6 \times 78.8$ \\
\hline 10------------------ & R4836 D (3) & $18.2 \times 74.6$ \\
\hline 11 ------------- & R4664 AQ (2) & $37.4 \times 98.2$ \\
\hline 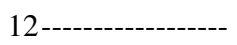 & R4705 E (2) & $17.9 \times 80.4$ \\
\hline $13---$ & R4664 A (3) & $23.7 \times 82.8$ \\
\hline $14-----$ & R4663 C (4) & $33.4 \times 95.2$ \\
\hline 15 ------------------ & R4664 AQ (2) & $32.3 \times 86.3$ \\
\hline 16, 17 ------------ & R4664 O (3) & $26.0 \times 95.7$ \\
\hline 18 ----------------- & R4664 V (4) & $18.9 \times 81.0$ \\
\hline \multicolumn{3}{|c|}{ Plate 6} \\
\hline 1 (------------------- & R4705 E (2) & $29.8 \times 95.6$ \\
\hline 2 ------------------- & R4664 AG (4) & $34.6 \times 69.6$ \\
\hline $3----$ & R4705 I (3) & $23.0 \times 91.7$ \\
\hline 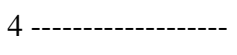 & R4664 V (4) & $18.3 \times 78.9$ \\
\hline 5 ----------------- & R4581 R (1) & $28.8 \times 104.8$ \\
\hline 6, 10 -------------- & R4836 C (3) & $32.4 \times 80.8$ \\
\hline 7 -------------------- & R4664 K (1) & $35.1 \times 91.8$ \\
\hline 8 -------------- & R4705 B (3) & $28.9 \times 94.8$ \\
\hline 9 ------------------ & R4664 AQ (2) & $22.0 \times 74.4$ \\
\hline 11 ------------------ & R4664 L (1) & $26.9 \times 83.5$ \\
\hline 12 ------------------ & R4581 V (4) & $18.3 \times 79.0$ \\
\hline 13 ------------ & R4664 D (4) & $35.3 \times 92.6$ \\
\hline 14------------------ & R4664 E (4) & $18.9 \times 72.1$ \\
\hline 15 ------------------- & R4663 C (4) & $31.4 \times 91.4$ \\
\hline 16------------------ & R4581 R (1) & $22.7 \times 73.5$ \\
\hline 17 ----------------- & R4664 AS (1) & $25.3 \times 86.8$ \\
\hline 18----------------- & R4664 D (4) & $29.0 \times 81.0$ \\
\hline
\end{tabular}




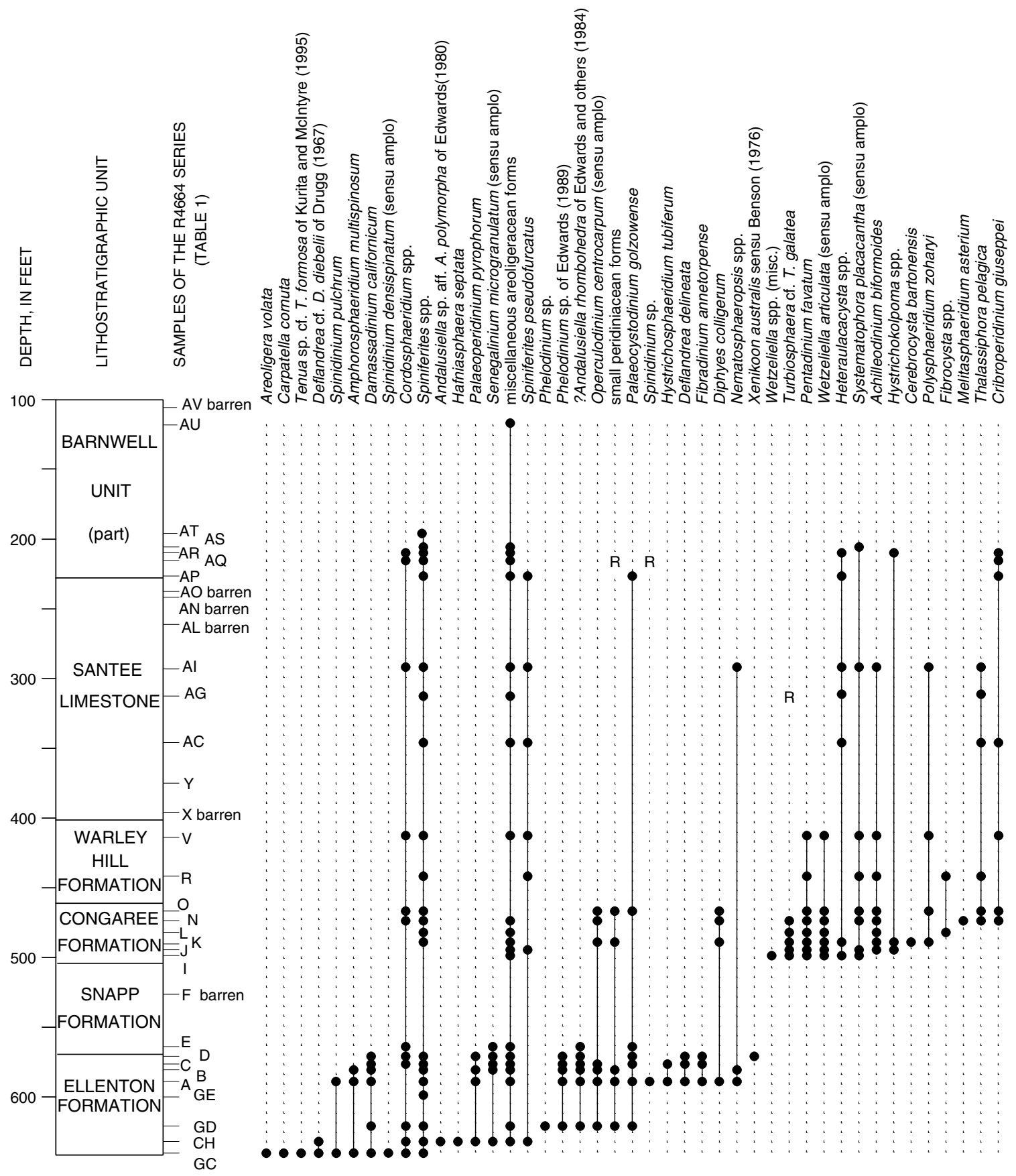

Figure 2. Range and occurrence chart of dinocysts and acritarchs in the Millhaven core. Lithostratigraphy from Falls and Prowell (this volume, chap. A). $\mathrm{R}=$ reworked; $\mathrm{cf}=$ compares with; ?=questionably identified; $1=$ single specimen. 


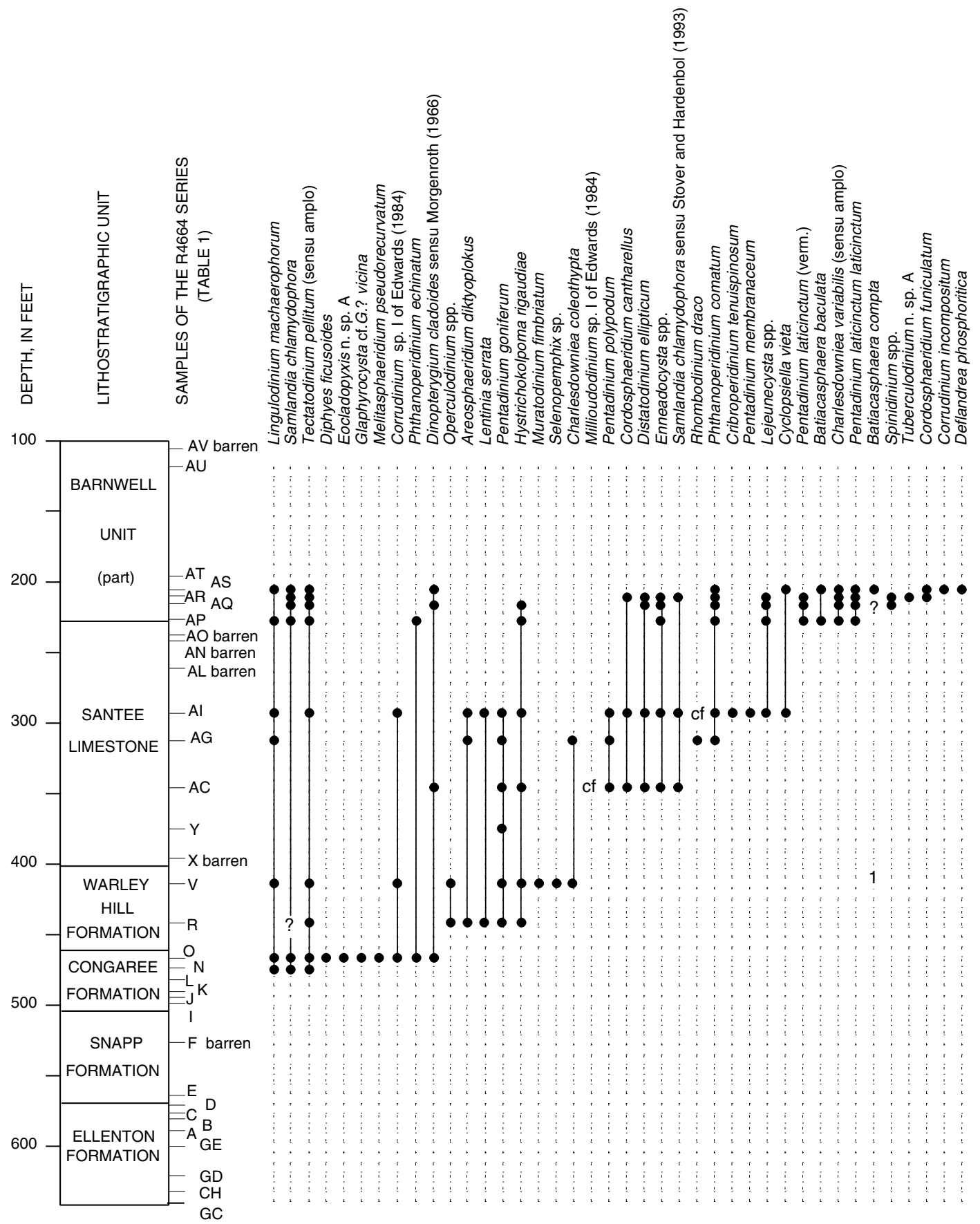

Figure 2. Continued. 
assigned to the early late Paleocene calcareous nannofossil Zone NP 5, but the uppermost part of the Ellenton (above $578 \mathrm{ft}$ ) has been placed in the middle late Paleocene Zone NP 8 (Bybell, this volume, chap. F).

\section{SNAPP FORMATION (570-504 ft)}

A single sample in the Snapp Formation (R4664 E, at 564-565 ft) produced rare, small peridiniacean dinocysts (pl. 6, fig. 14), as well as miscellaneous areoligeracean forms and Cordosphaeridium Eisenack sp. This Snapp Formation sample remains undated paleontologically. In this sample, the Snapp is at least marginally marine, unless all specimens are reworked. A higher sample (R4664 F, at 527 ft) did not contain dinocysts.

\section{FOURMILE BRANCH FORMATION (NOT PRESENT)}

The Fourmile Branch Formation is not present in the Millhaven core. Sediments containing marine middle Eocene dinocysts directly overlie the Snapp Formation.

\section{CONGAREE FORMATION (504-462 ft)}

The dinocyst assemblages in six samples in the Congaree Formation from 498.5-466 ft were studied. All contain Pentadinum favatum Edwards (pl. 3, fig. 15). The lower five samples (R4664 I, J, K, L, and N) contain Turbiosphaera cf. T. galatea (pl. 4, fig. 12), which is reported from the upper part of the Tallahatta Formation in Alabama (Edwards, 1977) and unit E3 of Prowell, Christopher, and others (1985). The absence of Hafniasphaera goodmanii Edwards suggests that these samples are of middle Eocene age, rather than early Eocene age, and that lower Eocene sediments are not present in this core. The calcareous nannofossils in these lower samples are assigned to Zone NP 14 (Bybell, this volume, chap. F).

The assemblage at $466 \mathrm{ft}(\mathrm{R} 4664 \mathrm{O})$ contains the lowest occurrence Glaphyrocysta cf. G.? vicina (pl. 2, figs. 1012) and appears to be correlative with the lowest part of the Lisbon Formation in Alabama (Edwards, unpub. data). This level could be assigned to either calcareous nannofossil Zone NP 14 or NP 15 (Bybell, this volume, chap. F).

\section{WARLEY HILL FORMATION (462-401 ft)}

Both Pentadinium favatum Edwards and Pentadinium goniferum Edwards are present in the samples of the Warley Hill Formation at 442 and $413 \mathrm{ft}$ (R4664 R and V). These species overlap in a thin interval within the lower, but not lowest, part of the Lisbon Formation in Alabama, which has been dated as NP 15 or NP 16 (Wrenn, 1996). It is assigned to NP 15 in the Millhaven core. The dinocyst assemblages in these samples correspond to those reported in part of the unit E4 of Prowell, Christopher, and others (1985).

\section{SANTEE LIMESTONE (401-228 ft)}

Eight samples were examined for dinocysts within the Santee Limestone; four of these are barren. One sample (R4664 Y, at $375 \mathrm{ft}$ ) contained only two specimens, both of Pentadinium goniferum Edwards. The three remaining samples (R4664 AC, at $346 \mathrm{ft}$; R4664 AG, at $313.5 \mathrm{ft}$; and R4664 AI, at $293 \mathrm{ft}$ ) produced well-preserved, diverse dinocysts that include Cordosphaeridium cantharellus (Brosius) Gocht (pl. 1, fig. 14), Distatodinium ellipticum (Cookson) Eaton, P. goniferum Edwards (pl. 3, fig. 16), Pentadinium polypodum Edwards (pl. 4, fig. 2), Rhombodinium draco Gocht (pl. 6, fig. 2), Samlandia chlamydophora Eisenack sensu Stover and Hardenbol (1993) (pl. 4, fig. 4), and Areosphaeridium diktyoplokum (Klumpp) Eaton. This assemblage is typical of the late middle Eocene and suggests correlation with the upper part of the Lisbon Formation or the Gosport Sand in Alabama. Three samples higher in the Santee (R4664 AL, at $260 \mathrm{ft}$; R4664 AN, at $242.5 \mathrm{ft}$; and R4664 AO, at $237.5 \mathrm{ft}$ ), as well as one near its base (R4664 X, at $396 \mathrm{ft})$, are barren. Santee sediments above $368 \mathrm{ft}$ in the Millhaven core have been assigned to late middle Eocene calcareous nannofossil Zone NP 17 (Bybell, this volume, chap. F).

\section{BARNWELL UNIT (228-0 ft)}

Seven samples from the Barnwell unit were examined for dinocysts; four were productive, and three are barren or contain only a single specimen.

Samples from the Barnwell unit are above the highest appearance of $P$. goniferum Edwards and are most likely of late Eocene age. The basal Barnwell sample (R4664 AP, at $227.5 \mathrm{ft}$ ) contains the lowest occurrence of Charlesdowniea variabilis (Bujak) Lentin \& Vozzhennikova and Batiacasphaera baculata Drugg (pl. 1, fig. 7). Higher samples (R4664 AR, at $210 \mathrm{ft}$, and R4664 AS, at $205 \mathrm{ft}$ ) contain $B$. baculata Drugg or Batiacasphaera compta Drugg (pl. 1, figs. 8-9) or both, which suggest correlation with the upper Eocene Yazoo Clay in Alabama, and Cordosphaeridium funiculatum Morgenroth (pl. 1, fig. 11), which is found in the Gosport Sand and Moodys Branch Formation (upper middle Eocene) in Alabama and the Parkers Ferry and Harleyville Formations (lower part of the Cooper Group, upper Eocene) in South Carolina (Edwards, 1977; unpub. data). Three samples above $205 \mathrm{ft}$ are barren or nearly so (R4664 AT, AU, AV, at 195, 118 and $105 \mathrm{ft}$, respectively). Barnwell sediments in the Millhaven core have been assigned to calcareous nannofossil Zones NP 17 and 19/2021(?) (Bybell, this volume, chap. F). 


\section{DINOCYSTS FROM THE GIRARD CORE}

Sixteen samples were taken for dinocysts in the Tertiary sediments from the Girard core and all but two contained dinocysts. The occurrences of dinocyst taxa in this core are shown in figure 3.

\section{ELLENTON FORMATION (542-481 ft)}

Dinocysts in the Paleocene Ellenton Formation in the Girard core were studied from five samples from 532.7 to $484.1 \mathrm{ft}$. As in the Millhaven core, both early Paleocene and late Paleocene assemblages were recorded.

The lowest sample (R4705 A, at 532.5-532.7 ft) contains a nondiagnostic dinoflora consisting of small peridiniacean cysts, Spiniferites Mantell spp., and a few specimens of the areoligeracean group. The next higher samples (R4705 B, at 521.0-521.2 and R4705 AD, at 517.9-518.1) contain early Paleocene (Danian, Midwayan) dinocysts, including Carpatella cornuta Grigorovich, Tenua sp. cf. T. formosa of Kurita and McIntyre (1995) (pl. 4, fig. 7), Tectatodinium rugulatum (Hansen) McMinn (pl. 4, figs. 10, 11) and Deflandrea n. sp. aff. D. truncata Stover (pl. 5, fig. 8). This assemblage is also dominated by small peridiniacean cysts. The sample R4705 C (at 514.0-514.3 ft) contains a rather sparse dinoflora that includes a fragment questionably identified as $C$. cornuta Grigorovich. The sample R4705 D (at 484.1-484.3 ft) contains a typical late Paleocene (Selandian, late Midwayan) dinoflora, which is also dominated by small peridiniacean cysts and contains Damassadinium californicum (Drugg) Fensome et al. and Phelodinium sp. of Edwards (1989).

\section{SNAPP FORMATION (481-423 ft)}

No samples were taken from the sand and clay of the Snapp Formation in the Girard core.

\section{FOURMILE BRANCH FORMATION (423-390 ft)}

Two samples were studied within the Fourmile Branch Formation. The age of these samples is Eocene. However, attempts to determine whether they are early or middle Eocene were inconclusive. In the lower sample (R4705 AE, at 415.2-415.5 ft), Homotryblium tenuispinosum Davey \& Williams is tentatively identified. A nearby repeat sample (R4705 CF, at $415 \mathrm{ft}$ ) recovered a single specimen of Dracodinium varielongitudum (Williams \& Downie) Costa \& Downie (pl. 5, fig. 7).

\section{CONGAREE FORMATION (390-325 ft)}

Two samples were studied within the Congaree Formation. The lower sample (R4705 E, at 362-362.3 ft) contains a variety of middle Eocene dinocysts that suggest correlation with the lower part of the Lisbon Formation in Alabama. Important species include Pentadinium favatum Edwards, Corrudinium sp. I of Edwards (1984), Phthanoperidinium echinatum Eaton, Pseudorhombodinium lisbonense Wrenn (pl. 6, fig. 1), Samlandia chlamydophora Eisenack, Wetzeliella articulata Eisenack, Glaphyrocysta cf. G.? vicina (pl. 2, fig. 13), and Eocladopyxis Morgenroth n. sp. A (pl. 2, fig. 7). The higher Congaree sample (R4705 $\mathrm{AF}$, at 327.3-327.5 ft) contains a similar dinocyst assemblage.

\section{WARLEY HILL FORMATION (NOT PRESENT)}

No samples containing both $P$. favatum Edwards and $P$. goniferum Edwards were found. Sediments correlative with the Warley Hill in the Millhaven core apparently are not present in the Girard core.

\section{SANTEE LIMESTONE (325-250 ft)}

Three samples were examined from the Santee Limestone in the Girard core. The lowest Santee sample (R4705 $\mathrm{F}$, at 322.3-322.5 ft) contains a very sparse and relatively nondiagnostic dinocyst assemblage. It does, however, contain the middle Eocene species Pentadinium goniferum Edwards. The sample a foot higher (R4705 G, at 321.4$321.6 \mathrm{ft}$ ) contains the lowest occurrence of Cordosphaeridium cantharellus (Brosius) Gocht. The sample at 257.8-258 $\mathrm{ft}(\mathrm{R} 4705 \mathrm{H})$ contains a well-preserved, diverse dinocyst assemblage that includes Pentadinium polypodum Edwards, Samlandia chlamydophora Eisenack sensu Stover and Hardenbol (1993), and Enneadocysta spp. These and other species present are characteristic of upper middle Eocene sediments correlative with the upper Lisbon Formation and the Gosport Sand (Edwards, 1977; unpub. data) and with unit E5 of Prowell, Christopher, and others (1985).

\section{BARNWELL UNIT (250-0 ft)}

Four samples from the Barnwell unit were studied from the Girard core. Sample R4705 I (at 211.1-211.3 ft) contains the species Rhombodinium perforatum (Jan du Chêne \& Châteauneuf) Lentin \& Williams (pl. 6, fig. 3), Charlesdowniea variabilis (Bujak) Lentin \& Vozzhennikova, and Corrudinium incompositum (Drugg) Stover \& Evitt (pl. 1, fig. 15). These species suggest a late middle or late Eocene age. The sample R4705 J (at 146.6-146.8 ft) contains a very sparse and nondiagnostic dinocyst 


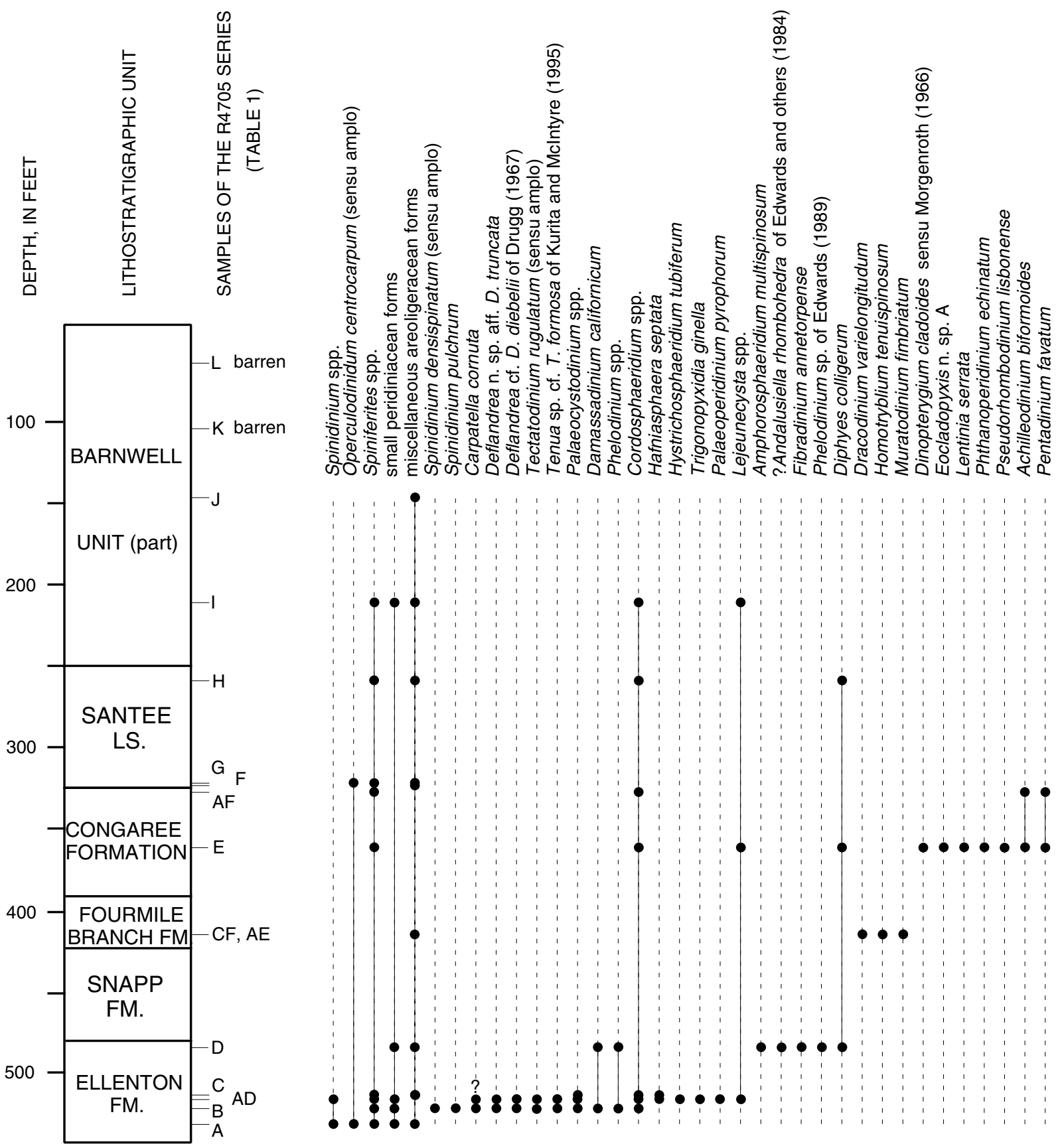

Figure 3. Range and occurrence chart of dinocysts and acritarchs in the Girard core. Lithostratigraphy from Falls and Prowell (this volume, chap. A). $\mathrm{cf}=$ compares with; ?=questionably identified. 

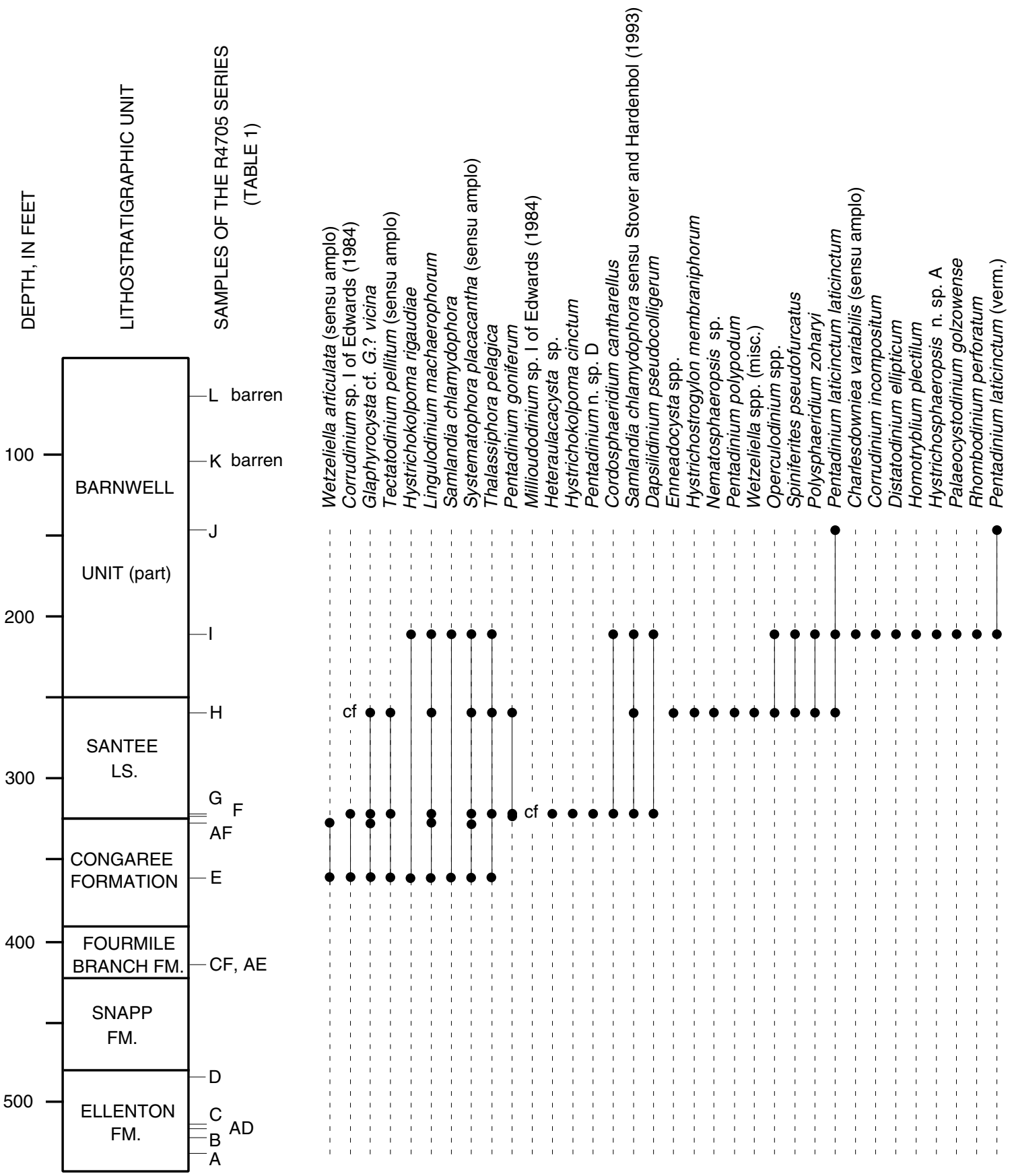

Figure 3. Continued. 
assemblage. Samples R4705 K and L (at 103.6-103.8 and $64.1-64.3 \mathrm{ft})$ are barren of dinocysts.

\section{DINOCYSTS FROM THE THOMPSON OAK CORE}

Sixteen samples were taken for dinocysts in the Tertiary sediments of the Thompson Oak core, and all contained dinocysts. The occurrences of dinocyst taxa in the Thompson Oak core are shown in figure 4.

\section{ELLENTON FORMATION (324-274 ft)}

Dinocysts in the Ellenton from the Thompson Oak core were studied from two samples. Both are Paleocene (Danian or Selandian, Midwayan). The lower sample ( $\mathrm{R} 4836 \mathrm{C}$, at $302 \mathrm{ft}$ ) is dominated by Areoligera volata Drugg and small peridiniaceans. Important species present include Tectatodinium rugulatum (Hansen) McMinn, Damassadinium californicum (Drugg) Fensome et al., Tепиа sp. cf. T. formosa of Kurita and McIntyre (1995), and Deflandrea n. sp. aff. D. truncata Stover. The sample lacks Carpatella cornuta Grigorovich but contains other species recorded in the early Paleocene samples from the Millhaven, Girard, and Millers Pond cores. The upper sample ( $\mathrm{R} 4836 \mathrm{D}$, at $281 \mathrm{ft}$ ) is dominated by small peridiniaceans and contains Andalusiella sp. aff. A. polymorpha of Edwards (1980) (pl. 5, fig. 4) and Phelodinium sp. of Edwards (1989). It is of late Paleocene age (Selandian).

\section{SNAPP FORMATION (NOT PRESENT)}

The Snapp Formation is not present in the Thompson Oak core. Sediments containing marine Eocene dinocysts directly overlie marine Paleocene sediments.

\section{FOURMILE BRANCH FORMATION (274-251 ft)}

Two samples from 269 and $245 \mathrm{ft}$ contain early Eocene dinocysts, including Hafniasphaera goodmanii Edwards (pl. 3, fig. 1), primitive forms of Pentadinium favatum Edwards, and Wetzeliella articulata Eisenack. The lowest of these contains Homotryblium abbreviatum Eaton (pl. 3, fig. 11). These assemblages are likely to be of early Eocene age.

\section{CONGAREE FORMATION (251-182 ft)}

Six samples in the Congaree from the Thompson Oak core were studied for dinocysts. The lowest sample (R4836 $\mathrm{G}$ from $245 \mathrm{ft}$ ) contains the highest occurrence of Hafniasphaera goodmanii Edwards. Five samples from 231.5$183.5 \mathrm{ft}$ all contain dinofloras that are roughly correlative with the upper part of the Tallahatta Formation and the lower part of the Lisbon Formation in Alabama. Sample $\mathrm{R} 4836 \mathrm{H}$ (at $231.5 \mathrm{ft}$ ) is more likely correlative with the upper part of the Tallahatta because it contains Turbiosphaera cf. T. galatea. The three samples from 194-183 ft (R4836 J, K, and L) are more likely correlative with the lower part of the Lisbon because they contain Glaphyrocysta cf. G.? vicina (pl. 2, fig. 14). Sample R4836 I (at 210 $\mathrm{ft}$ ) does not contain sufficient diagnostic taxa.

\section{WARLEY HILL FORMATION (NOT PRESENT)}

The Warley Hill Formation is not present in the Thompson Oak core.

\section{SANTEE LIMESTONE (182-130 ft)}

Six samples of the Santee Limestone were studied from the Thompson Oak core. The five samples from 181.5-154 ft depth contain a distinctive dinocyst assemblage that includes Pentadinum goniferum Edwards, Pentadinium Gerlach n. sp. D (pl. 3, figs. 19-21), Enneadocysta Stover \& Williams spp., Heteraulacacysta porosa Bujak, and Hystrichostrogylon membraniphorum Agelopoulos (pl. 3 , fig. 13). These forms indicate an age in the later part of the middle Eocene and correlation with the upper part of the Lisbon Formation, the Gosport Sand, or the Moodys Branch Formation in the Gulf Coast. The highest Santee Limestone sample (R4836 R, at $138 \mathrm{ft}$ ) contains the lowest occurrence of Cordosphaeridium cantharellus (Brosius) Gocht.

\section{BARNWELL UNIT (130-0 ft)}

Sediments of the Barnwell unit in the Thompson Oak core were not sampled in this study.

\section{DINOCYSTS FROM THE MILLERS POND CORE}

Nine samples were taken in Tertiary sediments of the Millers Pond core; seven contained dinocysts, and the uppermost two samples are barren. The occurrences of dinocyst taxa in this core are shown in figure 5 .

\section{ELLENTON FORMATION (284-232 ft)}

Dinocysts in the Ellenton Formation from the Millers Pond core were studied from two samples (R4581 Q, at 252-257 ft; R4581 R, at 237-242 ft). Both contain dinocyst assemblages of Paleocene age (Danian or Selandian, Midwayan). The lower sample contains Areoligera volata Drugg (pl. 1, fig. 5), Carpatella cornuta Grigorovich, Spini- 


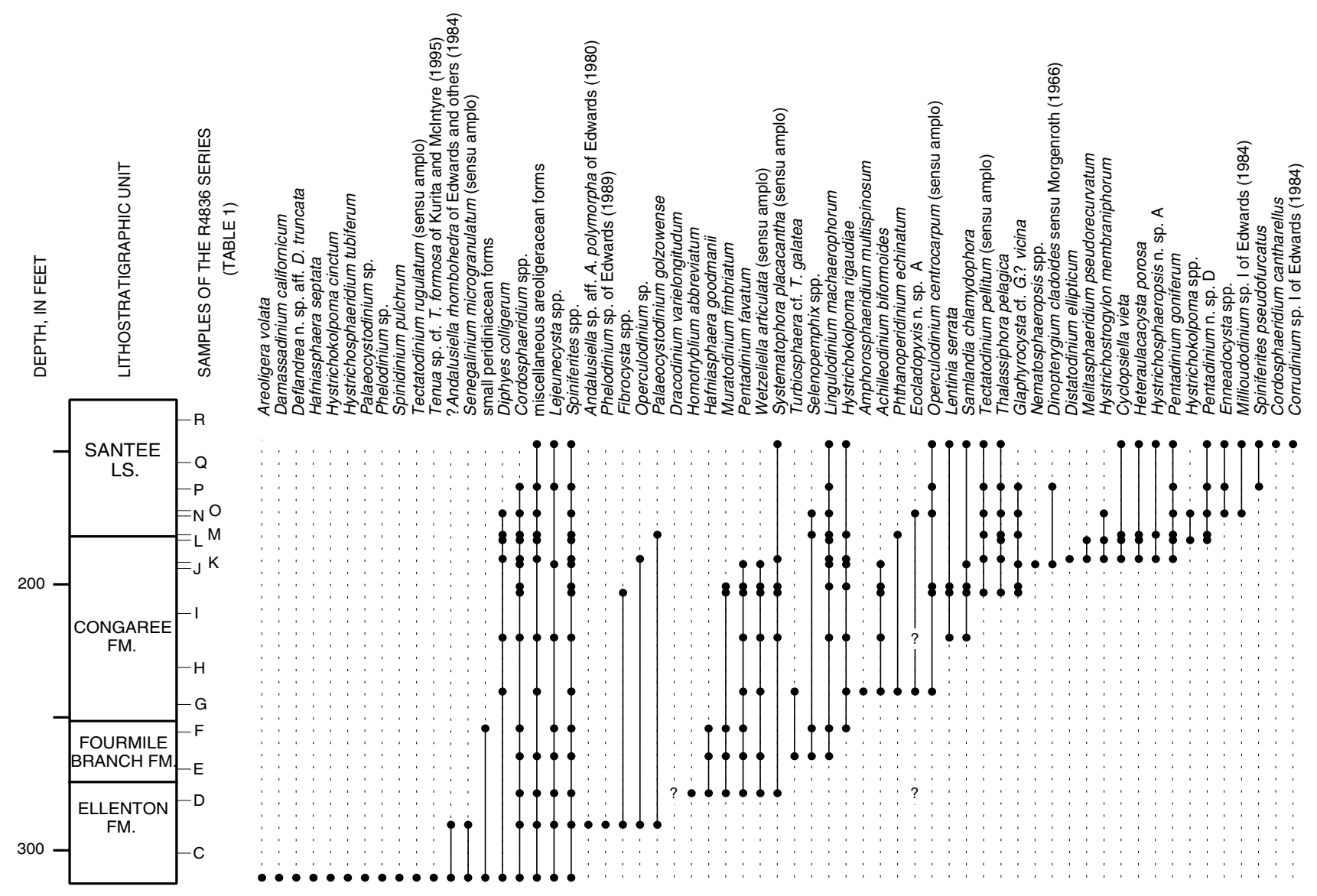

Figure 4. Range and occurrence chart of dinocysts and acritarchs in the Thompson Oak core. Lithostratigraphy from Falls and Prowell (this volume, chap. A). ?=questionably identified.

dinium densispinatum Stanley, Spinidinium pulchrum (Benson) Lentin \& Williams, Tectatodinium rugulatum (Hansen) McMinn, and Tenua sp. cf. T. formosa of Kurita and McIntyre (1995). C. cornuta has not been reported from sediments younger than early Paleocene. This sample contains early Paleocene pollen (Frederiksen, this volume, chap. H).

The upper sample in the Ellenton contains a distinctive assemblage including Andalusiella sp. aff. A. polymorpha of Edwards (1980) (pl. 5, fig. 3), Deflandrea cf. D. diebelii of Drugg (1967), Senegalinium microgranulatum (Stanley) Stover \& Evitt (pl. 6, fig. 5), Isabelidinium viborgense sensu Kurita and McIntyre (1995), and Damassadinium californicum (Drugg) Fensome et al. The species in this upper sample were reported together in the Porters Creek Clay in Alabama (Edwards, 1980). However, the assemblage could perhaps range into slightly younger sediments, because the Naheola Formation was not included in the 1980 study. Kurita and McIntyre (1995) used the lowest occurrence of $I$. viborgense Heilmann-Clausen to mark the base of the Selandian (earliest late Paleocene) in Manitoba, Canada.

\section{SNAPP FORMATION (232-165 ft)}

The interval from 232 to $165 \mathrm{ft}$ in the core consisted of coarse sand and thoroughly oxidized kaolinitic clay and was not sampled for dinocysts.

\section{FOURMILE BRANCH FORMATION (NOT PRESENT)}

The Fourmile Branch Formation is not present in the Millers Pond core. There is no evidence of early Eocene marine deposition in this core.

\section{CONGAREE FORMATION (165-156 ft)}

Directly above the oxidized clays of the Snapp Formation is a 9-ft-thick unit of silty sand. A sample just above the base (R4581 S, at $165 \mathrm{ft}$ ) contains a dinocyst assemblage that includes Diphyes colligerum (Deflandre \& Cookson) Cookson, Phthanoperidinium echinatum Eaton, Polysphaeridium zoharyi (Rossignol) Bujak et al., somewhat primitive 


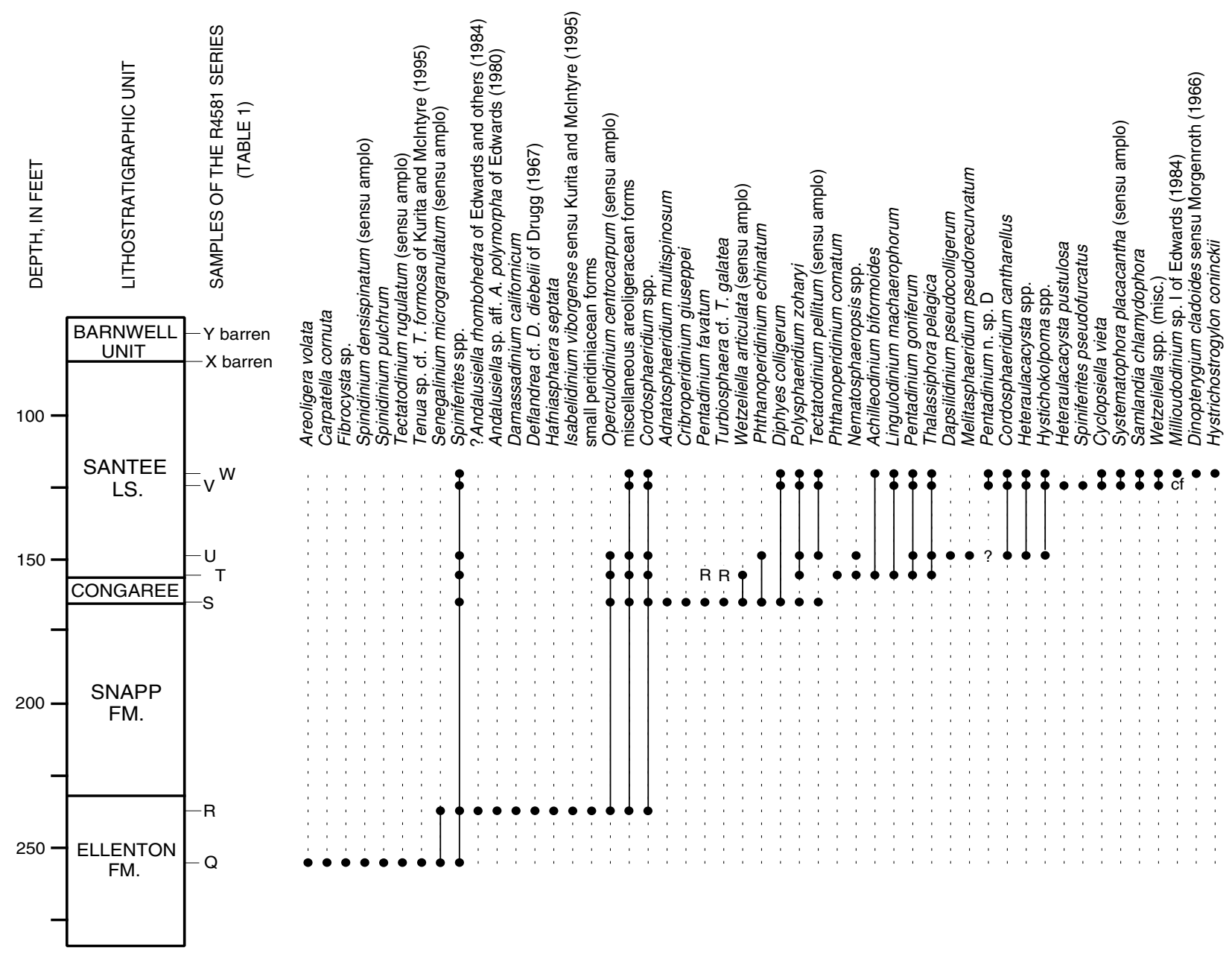

Figure 5. Range and occurrence chart of dinocysts and acritarchs in the Millers Pond core. Lithostratigraphy from Falls and Prowell (this volume, chap. A). R=reworked; $\mathrm{cf}=$ compares with; ?=questionably identified.

forms of Pentadinium favatum Edwards, Turbiosphaera cf. T. galatea, and Wetzeliella articulata Eisenack. This assemblage correlates with that recorded from the upper part of the Tallahatta Formation in Alabama, which is in the lower part of the middle Eocene.

\section{WARLEY HILL FORMATION (NOT PRESENT)}

The Warley Hill Formation is not present in the Millers Pond core.

\section{SANTEE LIMESTONE (156-82 ft)}

Five samples from the Santee Limestone were studied from the Millers Pond core. The lowest sample (R4581 T, at $155 \mathrm{ft}$ ) contains a diverse dinocyst assemblage including Achilleodinium biformoides (Eisenack) Eaton and Pentadinium goniferum Edwards, and single specimens of Pentadinium favatum Edwards and Turbiosphaera cf. T. galatea.
This assemblage could represent the interval of overlap of the ranges of $P$. favatum Edwards and $P$. goniferum Edwards, or it could represent a lag deposit at the base of the overlying unit. Because P. favatum Edwards and Turbiosphaera cf. T. galatea are each represented by one poorly preserved specimen, and because Turbiosphaera cf. $T$. galatea and P. goniferum Edwards do not overlap in other cores, the interpretation of this sample as a lag deposit appears more likely.

Three samples (R4581 U, V, W, at 148, 124, and 120 ft) contain diverse and abundant dinocyst assemblages including Pentadinium goniferum Edwards, Pentadinium Gerlach n. sp. D, Samlandia chlamydophora Eisenack, Hystrichostrogylon coninckii Heilmann-Clausen, Cordosphaeridium cantharellus (Brosius) Gocht, and Dapsilidinium pseudocolligerum (Stover) Bujak et al. This is a late middle Eocene assemblage, correlative with the upper part of the Lisbon Formation, Gosport Sand, or Moodys Branch Formation in Alabama. The uppermost 


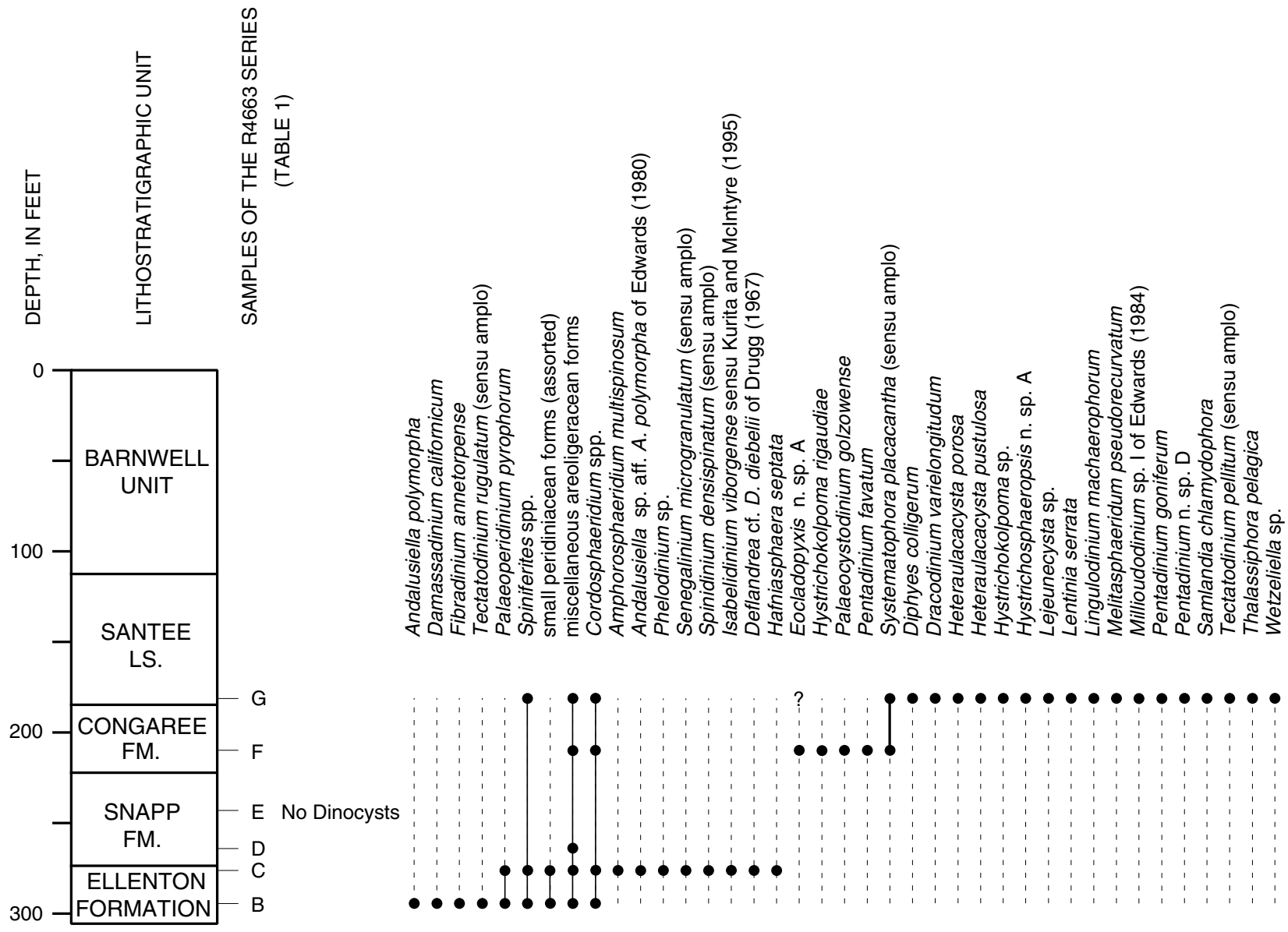

Figure 6. Range and occurrence chart of dinocysts and acritarchs in the McBean core. Lithostratigraphy from Falls and Prowell (this volume, chap. A). ?=questionably identified.

sample in the Santee Limestone (R4581 X, at $82-83 \mathrm{ft}$ ) is barren of dinocysts.

\section{BARNWELL UNIT (82-0 ft)}

Barnwell unit sediments were examined for dinocysts in a single sample at $72-77 \mathrm{ft}$ in the Millers Pond core. The sample proved barren.

\section{DINOCYSTS FROM THE MCBEAN CORE}

Six samples were taken in Tertiary sediments of the McBean core; five contained dinocysts and one yielded only pollen. The occurrences of dinocyst taxa in this core are shown in figure 6 .

\section{ELLENTON FORMATION (305-272 ft)}

Two samples from the Ellenton Formation in the McBean core yielded Paleocene (Danian or Selandian, Mid- wayan) dinocyst assemblages. The lower sample (R4663 B, at $294 \mathrm{ft}$ ) includes Damassadinium californicum (Drugg) Fensome et al. (pl. 2, figs. 1-2), Palaeoperidinium pyrophorum (Ehrenberg) Sarjeant, and Tectatodinium rugulatum (Hansen) McMinn. The upper sample (R4663 C, at $276 \mathrm{ft}$ ) includes Andalusiella sp. aff. A. polymorpha of Edwards (1980), Deflandrea cf. D. diebelii of Drugg (1967), Hafniasphaera septata (Cookson \& Eisenack) Hansen, Isabelidinium viborgense sensu Kurita and McIntyre (1995) (pl. 5, fig. 2), and P. pyrophorum (Ehrenberg) Sarjeant. The lower sample is likely to be early Paleocene, as indicated by the presence of T. rugulatum (Hansen) McMinn. The upper sample is late Paleocene (Selandian, Midwayan) because of the presence of I. viborgense sensu Kurita and McIntyre (1995).

\section{SNAPP FORMATION (272-222 ft)}

A single fragmental specimen of the areoligeraceae group was recovered from the sample of the Snapp Forma- 
tion at $264 \mathrm{ft}$ (R4663 D) in the McBean core. A second sample (R4663 E, at $243 \mathrm{ft}$ ) yielded no dinocysts.

\section{FOURMILE BRANCH FORMATION (NOT PRESENT)}

The Fourmile Branch Formation is not recognized in the McBean core.

\section{CONGAREE FORMATION (222-186 ft)}

A single sample of the Congaree Formation in the McBean core (R4663 F, at $210 \mathrm{ft}$ ) contains the early middle Eocene species Eocladopyxis Morgenroth n. sp. A and Pentadinium favatum Edwards, and long-ranging species.

\section{WARLEY HILL FORMATION (NOT PRESENT)}

The Warley Hill Formation is not recognized in the McBean core.

\section{SANTEE LIMESTONE (186-112 ft)}

A single sample of the Santee Limestone in the McBean core (R4663 G, at $181 \mathrm{ft}$ ) yielded a diverse middle Eocene dinocyst assemblage. Heteraulacacysta porosa Bujak, Heteraulacacyata pustulosa Jan du Chêne \& Adediran (pl. 3, fig. 5), Pentadinium goniferum Edwards, and Samlandia chlamydophora Eisenack are present. The assemblage resembles that in the Santee Limestone in the Thompson Oak core.

\section{BARNWELL UNIT (112-0 ft)}

Sediments of the Barnwell unit from the McBean core were not sampled in this study.

\section{DISCUSSION}

Paleocene sediments in the cores studied include two separate assemblages. The older one is early Paleocene (Danian, Midwayan) and contains Carpatella cornuta Grigorovich, Spinidinium pulchrum (Benson) Lentin \& Williams (pl. 6, figs. 6, 10), Tectatodinium rugulatum (Hansen) McMinn, and Tenиa sp. cf. T. formosa of Kurita and McIntyre (1995). This assemblage is assigned to calcareous nannofossil Zone NP 4 in the Millhaven core. The younger assemblage contains Phelodinium sp. of Edwards (1989) (pl. 5, fig. 10) and is assigned to calcareous nannofossil Zones NP 5 and NP 8 in the Millhaven core (Bybell, this volume, chap. F). Both assemblages contain Damassadinium californicum (Drugg) Fensome et al., Palaeoperidinium pyrophorum (Ehrenberg) Sarjeant, and Deflandrea cf. D. diebelii of Drugg (1967) (pl. 5, fig. 6) and may be dominated by small peridiniaceans (pl. 6, figs. 13, 15, 16). Andalusiella sp. aff. A. polymorpha of Edwards (1980) and Isabelidinium viborgense sensu Kurita and McIntyre (1995) may be found just below, and in the lower part of, the upper assemblage. Kurita and McIntyre (1995) used the lowest occurrence of I. viborgense Heilmann-Clausen to approximate the early-late Paleocene (Danian-Selandian) boundary in Manitoba, Canada. In the Millhaven core, the uppermost Ellenton sample has been placed in calcareous nannofossil Zone NP 8 (Bybell, this volume, chap. F) although the dinocyst assemblage is not noticeably different from assemblages in the samples below it.

The Snapp Formation is present in varying thicknesses in four of the five cores. It is conspicuously absent in the Thompson Oak core, and an upper kaolinitic part is not present in the McBean core. Because the Snapp Formation is present in the most updip cores, it was probably also present in the Thompson Oak area originally but subsequently removed. Marginal marine or marine dinocysts are found in two samples of the lower part of the Snapp Formation in the Millhaven and McBean cores. However, the assemblages are not age diagnostic and could perhaps be reworked from the Ellenton.

Lower Eocene sediments are identified in the Fourmile Branch Formation in the Thompson Oak core on the basis of Hafniasphaera goodmanii Edwards and primitive forms of Pentadinium favatum Edwards. Homotryblium abbreviatum Eaton is also present. Sediments in the Fourmile Branch in the Girard core contain Dracodinium varielongitudum (Williams \& Downie) Costa \& Downie and Homotryblium tenuispinosum Davey \& Williams and may be of early Eocene age. Early Eocene dinocysts are conspicuously missing from the Millhaven, Millers Pond, and McBean cores.

Middle Eocene Congaree sediments correlative with the uppermost part of the Tallahatta Formation and the lower part of the Lisbon Formation are present in all cores. Samples contain diverse dinocyst assemblages, which include Achilleodinium biformoides (Eisenack) Eaton (pl. 1, figs. 1-3), Diphyes colligerum (Deflandre \& Cookson) Cookson, Eocladopyxis Morgenroth n. sp. A, Glaphyrocysta cf. G.? vicina, Phthanoperidinium echinatum Eaton (pl. 5, figs. 16, 17), Pentadinium favatum Edwards, Samlandia chlamydophora Eisenack (pl. 4, fig. 3), Turbiosphaera cf. T. galatea, Wetzeliella articulata Eisenack (pl. 6, figs. 7, 11), and many areoligeracean forms. The highest occurrence of Turbiosphaera cf. T. galatea and the lowest occurrence of Glaphyrocysta cf. G.? vicina may mark an important level, correlative with the Tallahatta Formation-Lisbon Formation boundary in Alabama and the E3-E4 boundary (of Prowell, Christopher, and others, 1985) in Georgia. Calcareous nannofossils in the Millhaven core indicate that this boundary is near the NP 14/NP 15 boundary. 
Sediments containing both Pentadinium favatum Edwards and Pentadinium goniferum Edwards are found only in the Millhaven core. It is here they are assigned to the Warley Hill Formation (Falls and Prowell, this volume, chap. A) and to calcareous nannofossil Zone NP 15 (Bybell, this volume, chap. F).

Middle Eocene sediments correlative with the upper part of the Lisbon Formation and the Gosport Sand in Alabama are present in the Santee Limestone in all cores. Assemblages vary from quite diverse to poorly preserved and nondiagnostic. Pentadinium goniferum Edwards is present in every sample. The lowest occurrences of Cordosphaeridium cantharellus (Brosius) Gocht, Cyclopsiella vieta Drugg \& Loeblich, and Dapsilidinium pseudocolligerum (Stover) Bujak et al. (pl. 1, fig. 18) are found in the Santee Limestone. Hystrichosphaeropsis Deflandre n. sp. A (pl. 3, figs.7-9), Pentadinium Gerlach n. sp. D, and Pentadinium polypodum Edwards are apparently restricted to the Santee Limestone. Enneadocysta spp., various species of Heteraulacacysta, and a wide variety of areoligeracean forms are present in the more diverse samples. Species of Wetzeliella (pl. 6, fig. 12) are present in a few samples but are not common.

In the Millhaven and Girard cores, the lowest samples in the Santee Limestone are barren or nearly so. In the Millhaven core, the sample at $346 \mathrm{ft}$ contains the lowest occurrences of Cordosphaeridium cantharellus (Brosius) Gocht, Pentadinium polypodum Edwards, and Samlandia chlamydophora Eisenack sensu Stover and Hardenbol (1993). Here, the lowest occurrence of Cordosphaeridium cantharellus (Brosius) Gocht approximates the base of calcareous nannofossil Zone NP 17 (Bybell, this volume, chap. F). In the Girard core, the lowest occurrence of Cordosphaeridium cantharellus (Brosius) Gocht is just above the base of the Santee Limestone.

Dinocyst recovery is spotty in sediments of the Barnwell unit. In the Millhaven core, samples contain Batiacasphaera baculata Drugg, Batiacasphaera compta Drugg, and Cordosphaeridium funiculatum Morgenroth, which indicate a late Eocene age. In the Girard core, Rhombodinium perforatum (Jan du Chêne \& Châteauneuf) Lentin \& Williams is diagnostic. Both cores contain Charlesdowniea variabilis (Bujak) Lentin \& Vozzhennikova (pl. 5, fig. 11). In the remaining cores, samples were not taken in Barnwell sediments, except one sample, which was barren (table 1).

Figure 7 shows core-to-core correlations suggested by the dinocyst assemblages. Lower Paleocene sediments are present in all cores, but these may be thicker in the updip cores (McBean, Millers Pond, and Thompson Oak) than in the most downdip core (Millhaven). The younger part of the Ellenton is thinnest in the updip cores.

The Snapp Formation is missing from the Thompson Oak core and truncated in the McBean core. The Fourmile Branch Formation is recognized only in the Girard and Thompson Oak cores. In the Thompson Oak core, the absence of the Snapp corresponds with the presence of the Fourmile Branch and a thickened Congaree relative to other cores.

The Congaree Formation is middle Eocene. It contains two recognizable dinocyst assemblages, which are equivalent to those found in the upper part of the Tallahatta Formation and the lower part of the Lisbon Formation in Alabama. The Warley Hill Formation is recognized only in the most basinward core (Millhaven).

The Tertiary units in the Burke and Screven County cores studied here show a much more complex history than was anticipated. In these generally shallow marine sediments, local patterns of erosion and deposition are important. A paleo-Savannah River may have wholly or partially eroded units such as the Snapp Formation to allow selective infilling, or selective preservation of more widespread infilling, during later transgressions.

\section{TAXONOMIC NOTES}

The species present are listed in Williams and others (1998) and their taxonomic history is not repeated here. Brief synonymies are provided for dinocysts that are presented in open or informal nomenclature. Higher level taxonomy is taken from Fensome and others (1993). Taxa are presented alphabetically by order. For convenience, dates are provided with the authors' names for formal taxa; the works these represent are not included in the references here but may be found in Williams and others (1998). Table 2 provides the slide locations of all figured specimens.

Division DINOFLAGELLATA (Butschli 1885) Fensome et al. 1993

Subdivision DINOKARYOTA Fensome et al. 1993

Class DINOPHYCEAE Pascher 1914

Subclass PERIDINIPHYCIDAE Fensome et al. 1993

Order GONYAULACALES Taylor 1980

ACHILLEODINIUM BIFORMOIDES

(EISENACK 1954) EATON 1976

Plate 1, figures 1-3

Remarks.-Both relatively smooth forms and those with striate processes are included.

\section{AMPHOROSPHAERIDIUM? MULTISPINOSUM (DAVEY \& WILLIAMS 1966) SARJEANT 1981} Plate 1, figure 4

AREOLIGERA VOLATA DRUGG 1967

Plate 1, figure 5

AREOSPHAERIDIUM DIKTYOPLOKUM (KLUMPP 1953) EATON 1971

Plate 1, figure 6

BATIACASPHAERA BACULATA DRUGG 1970

Plate 1, figure 7 


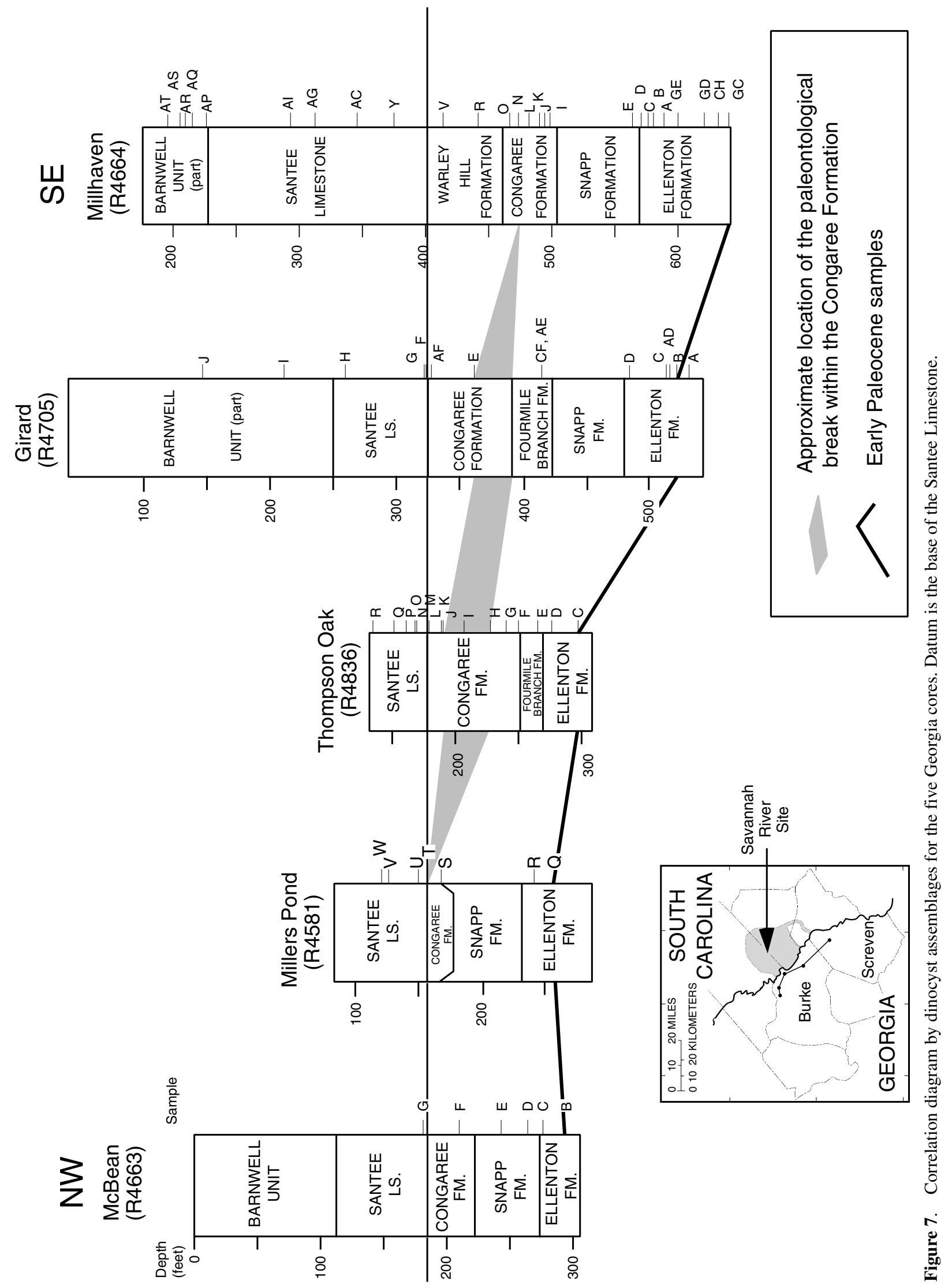




\author{
BATIACASPHAERA COMPTA DRUGG 1970 \\ Plate 1, figures 8,9
}

\section{CARPATELLA CORNUTA GRIGOROVICH 1969 \\ Plate 1, figure 10}

\section{CEREBROCYSTA BARTONENSIS BUJAK 1980}

Plate 1, figures 12,13

\section{CORDOSPHAERIDIUM CANTHARELLUS (BROSIUS 1963) GOCHT 1969 \\ Plate 1, figure 14}

Remarks.-Cordosphaeridium Eisenack 1963 is considered here to be the senior taxonomic synonym of Tityrosphaeridium Sarjeant 1981. The holotype of Cordosphaeridium inodes (Klumpp 1953) Eisenack 1963 clearly shows cingular processes in the illustration by Sarjeant (1981, text-fig. 1).

\section{CORDOSPHAERIDIUM FUNICULATUM MORGENROTH 1966 \\ Plate 1, figure 11}

\section{CORDOSPHAERIDIUM EISENACK 1963 SPP.}

Remarks.-The species Cordosphaeridium fibrospinosum Davey \& Williams 1966, Cordosphaeridium gracile (Eisenack 1954) Davey \& Williams 1966, Cordosphaeridium inodes (Klumpp 1953) Eisenack 1963, and forms between these endmembers are not differentiated in this study.

\section{CORRUDINIUM INCOMPOSITUM (DRUGG 1970) STOVER \& EVITT 1978 \\ Plate 1, figure 15 \\ CORRUDINIUM SP. I OF EDWARDS (1984) \\ Plate 1, figure 16}

Corrudinium sp. I. Edwards, 1984, pl. 2, fig. 1.

Remarks.-Some forms are transitional to Cerebrocysta bartonensis Bujak 1980.

CRIBROPERIDINIUM GIUSEPPEI (MORGENROTH 1966) HELENES 1984

Plate 1, figure 17

\section{CRIBROPERIDINIUM TENUITABULATUM} (GERLACH 1961) HELENES 1984

DAMASSADINIUM CALIFORNICUM (DRUGG 1967) FENSOME ET AL. 1993

Plate 2, figures 1-3

Remarks.-Both typical and elongate forms are included.

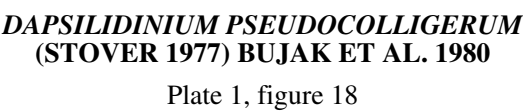

DINOPTERYGIUM CLADOIDES SENSU MORGENROTH 1966 Plate 2, figure 4
Dinopterygium cladoides Deflandre. Morgenroth, 1966, pl. 2, fig. 11.

Heteraulacacysta sp. Damassa and others, 1990, fig. 5E, F. Dinopterygium sp. Stover and Hardenbol, 1993, pl. 12, fig. 83.

\section{DIPHYES COLLIGERUM (DEFLANDRE \& COOKSON 1955) COOKSON 1965 \\ DIPHYES FICUSOIDES ISLAM 1983 \\ Plate 2, figure 5}

DISTATODINIUM ELLIPTICUM (COOKSON 1965) EATON 1976 Plate 2, figure 9

ENNEADOCYSTA STOVER \& WILLIAMS 1995 SPP. Plate 2, figure 6

Remarks.-Various species of the genus are included.

EOCLADOPYXIS MORGENROTH 1966 N. SP. A

Plate 2, figure 7

Remarks.-The processes resemble those of Polysphaeridium zoharyi (Rossignol 1962) Bujak et al. 1980, but the separation of the individual paraplates requires placement in the genus Eocladopyxis Morgenroth 1966.

\section{FIBRADINIUM ANNETORPENSE MORGENROTH 1968}

Plate 2, figure 8

FIBROCYSTA STOVER \& EVITT 1978 SPP.

Remarks.-Various species of the genus are included.

GLAPHYROCYSTA CF. G.? VICINA

(EATON 1976) STOVER \& EVITT 1978

Plate 2, figures $10-15$

Remarks.-This form is highly variable in the degree of development of the marginal flanges. It resembles Membranophoridium aspinatum Gerlach 1961 in overall appearance, but it is smaller, has less pronounced dorso-ventral compression, and has less prominent flanges. It resembles and may be transitional with Membranophoridium bilobatum Michoux 1985, which has narrower flanges and no development of pericoels other than along the margins. It is closest to Glaphyrocysta? vicina (Eaton 1976) Stover \& Evitt 1978. However, the paracingulum may be more pronounced, and the details of the dorsal and ventral surfaces may warrant separation.

\section{HAFNIASPHAERA GOODMANII EDWARDS 1982}

Plate 3, figure 1

Remarks.-The illustrated specimen, like most specimens seen, is actually transitional with primitive forms of Pentadinium favatum Edwards.

HAFNIASPHAERA SEPTATA

(COOKSON \& EISENACK 1967) HANSEN 1977

Plate 3 , figure 10 
HETERAULACACYSTA POROSA BUJAK 1980

Plate 3, figures 2, 3

\author{
HETERAULACACYSTA PUSTULOSA JAN DU CHÊNE \\ \& ADEDIRAN 1985 \\ Plate 3, figure 5
}

HETERAULACACYSTA DRUGG \& LOEBLICH 1967 SPP.

Plate 3 , figure 6

Remarks.-The species Heteraulacacysta campanula Drugg \& Loeblich 1967 and Heteraulacacysta? leptalea Eaton 1976 and poorly preserved specimens of the genus that are unattributable to species are placed here.

HOMOTRYBLIUM ABBREVIATUM EATON 1976

Plate 3, figure 11

HOMOTRYBLIUM PLECTILUM DRUGG \& LOEBLICH 1967

Plate 3, figure 12

HOMOTRYBLIUM TENUISPINOSUM DAVEY \& WILLIAMS 1966

HYSTRICHOKOLPOMA CINCTUM KLUMPP 1953

HYSTRICHOKOLPOMA RIGAUDIAE DEFLANDRE \& COOKSON 1955

HYSTRICHOKOLPOMA DEFLANDRE 1935 SPP.

Remarks.-Various species of the genus are included.

HYSTRICHOSPHAERIDIUM TUBIFERUM

(EHRENBERG 1838) DEFLANDRE 1937

HYSTRICHOSPHAEROPSIS DEFLANDRE 1935 N. SP. A

Plate 3, figures 7-9

Remarks.-This small, distinctive form has relatively high septa that are finely serrate distally.

HYSTRICHOSTROGYLON CONINCKII HEILMANN-CLAUSEN 1985

HYSTRICHOSTROGYLON MEMBRANIPHORUM AGELOPOULOUS 1964

Plate 3, figure 13

LINGULODINIUM MACHAEROPHORUM (DEFLANDRE \& COOKSON 1955) WALL 1967

MELITASPHAERIDIUM ASTERIUM

(EATON 1976) BUJAK ET AL. 1980

MELITASPHAERIDIUM PSEUDORECURVATUM

(MORGENROTH 1966) BUJAK ET AL. 1980

MILLIOUDODINIUM SP. I OF EDWARDS (1984)

Plate 3, figure 4

Millioudodinium sp. I. Edwards, 1984, pl. 2, fig. 2.

Cribroperidinium sp. 2. Damassa and others, 1990, fig. 4C. Cribroperidinium sp. 2. Firth, 1996, pl. 5, figs. 7, 8.

Remarks.-The honeycomb pattern in the intraplate areas is distinctive. This form now correctly belongs in the genus Cribroperidinium Neale \& Sarjeant 1962, emend. Helenes 1984.

MURATODINIUM FIMBRIATUM

(COOKSON \& EISENACK 1967) DRUGG 1970

NEMATOSPHAEROPSIS DEFLANDRE \& COOKSON 1955 SPP.

Remarks.-Various species of the genus are included.

OPERCULODINIUM CENTROCARPUM (DEFLANDRE \& COOKSON 1955) WALL 1967

Plate 3, figure 14

Remarks.-The species name is used in the broad sense.

OPERCULODINIUM WALL 1967 SPP.

Remarks.-Various species of the genus are included.

PENTADINIUM FAVATUM EDWARDS 1982

Plate 3, figure 15

PENTADINIUM GONIFERUM EDWARDS 1982

Plate 3, figure 16

PENTADINIUM LATICINCTUM GERLACH 1961 SUBSP. LATICINCTUM

Plate 3, figure 17

PENTADINIUM LATICINCTUM GERLACH 1961 (VERM.)

Plate 3, figure 18

Pentadinium laticinctum subsp. granulatum. Edwards, 1982, pl. 4, figs. 10, 11.

Pentadinium laticinctum (vermicular) Gerlach. Edwards, 1984, pl. 2, fig. 4.

Remarks.-Specimens of P. laticinctum Gerlach 1961 with a vermicular surface are separated from $P$. laticinctum Gerlach 1961 subsp. laticinctum. The vermicular surface differs from the granular surface of Pentadinium laticinctum subsp. granulatum Gocht 1969.

\section{PENTADINIUM MEMBRANACEUM (EISENACK 1965) STOVER \& EVITT 1978 \\ Plate 4, figure 1}

PENTADINIUM POLYPODUM EDWARDS 1982

Plate 4, figure 2

PENTADINIUM GERLACH 1961 N. SP. D

Plate 3, figures 19-21

Remarks. - In this undescribed form of Pentadinium Gerlach 1961, the periphragm in the paracingular region is separated from the endophragm only along the ventral side; the wall layers are appressed laterally and dorsally. The wall surface is smooth.

POLYSPHAERIDIUM ZOHARYI (ROSSIGNOL 1962) BUJAK ET AL. 1980 
ROTTNESTIA BORUSSICA (EISENACK 1954)

COOKSON \& EISENACK 1961

SAMLANDIA CHLAMYDOPHORA EISENACK 1954

Plate 4 , figure 3

\section{SAMLANDIA CHLAMYDOPHORA EISENACK SENSU STOVER} AND HARDENBOL (1993)

Plate 4, figure 4

Samlandia chlamydophora Eisenack 1954. Stover and Hardenbol, 1993, pl. 8, fig. 54 a,b.

Remarks.-This form has considerably more differentiation into separate penetabular process complexes than does the type of $S$. chlamydophora Eisenack 1954.

\section{SPINIFERITES PSEUDOFURCATUS (KLUMPP 1953) SARJEANT 1970 \\ Plate 4 , figure 5}

SPINIFERITES MANTELL 1850 SPP.

Remarks._-Various species of the genus are included.

SYSTEMATOPHORA PLACACANTHA (DEFLANDRE \& COOKSON 1955) DAVEY ET AL. 1969

Plate 4, figure 6

Remarks.-The species name is used in the broad sense. The process complexes are highly variable.

\section{TECTATODINIUM PELLITUM WALL 1967}

Plate 4 , figure 8

Remarks.-The species name is used in the broad sense. The wall thickness is highly variable. Although some specimens are assignable to Tectatodinium grande Williams et al. 1993, they are clearly only endmembers in a spectrum.

\section{TECTATODINIUM RUGULATUM (HANSEN 1977) MCMINN 1988}

Plate 4, figures 10, 11

Remarks.-The species name is used in the broad sense. The wall is thicker than the wall in the type specimen.

TENUA SP. CF. T. FORMOSA OF KURITA AND MCINTYRE (1995)

Plate 4 , figure 7

Tenua sp. cf. T. formosa (Mao \& Norris 1988) Lentin \& Williams 1993. Kurita and McIntyre, 1995, p. 134, pl. 2, fig. 15 .

Remarks. - Like the specimens reported by Kurita and McIntyre (1995), the specimens in the Georgia cores lack well-defined paratabulation. This form was encountered in three cores in the lowest samples from the Ellenton Formation. In four of the five samples, Carpatella cornuta Grigorovich was also present.

\section{THALASSIPHORA PELAGICA (EISENACK 1954)} EISENACK \& GOCHT 1960

\section{TRIGONOPYXIDIA GINELLA (COOKSON \& EISENACK 1960) DOWNIE \& SARJEANT 1965 \\ TUBERCULODINIUM WALL 1967 N. SP. A \\ Plate 4 , figure 9}

Remarks.-Only a few specimens of this form were encountered. It has a broad flange and faintly developed tubercules. The multiplate antapical archeopyle clearly indicates its affinity with Tuberculodinium Wall 1967.

\section{TURBIOSPHAERA CF. T. GALATEA EATON 1976 \\ Plate 4, figure 12}

?Lanternosphaeridium lanosum Morgenroth 1966. Drugg and Stover, 1975, pl. 5, fig. 2.

Remarks.-The Georgia form resembles Turbiosphaera galatea Eaton 1976, but the intratabular processes are not as well developed and may form a more or less continuous membrane that represents the postcingular and antapical areas. The endocyst may have a distinct apical boss. It is more elongate than L. lanosum Morgenroth sensu Drugg and Stover (1975).

\section{MISCELLANEOUS AREOLIGERACEAN FORMS \\ Plate 4, figures 13,14}

Remarks. - This category is used for the highly variable plexus that contains members of the genera Adnatosphaeridium, Areoligera, and Glaphyrocysta, except for the distinctive species listed separately.

Order PERIDINIALES Haeckel 1894

ANDALUSIELLA POLYMORPHA (MALLOY 1972) LENTIN \& WILLIAMS 1977

Remarks.-Broad forms with two distinct antapical horns were seen.

ANDALUSIELLA SP. AFF. A. POLYMORPHA OF EDWARDS (1980) Plate 5, figures 3,4

Andalusiella sp. aff. A. polymorpha (Malloy 1972) Lentin \& Williams 1977. Edwards, 1980, p. 9, fig. 1.

Andalusiella australinum (Cookson 1965) Lentin \& Williams 1977. Kurita and McIntyre (1995), pl. 1, fig. 12.

Remarks.-The two antapical horns are fused proximally. At one-third to one-half of the total length of the longer horn, they separate.

\section{?ANDALUSIELLA RHOMBOHEDRA OF EDWARDS AND OTHERS (1984) \\ Plate 5, figure 1}

?Andalusiella rhombohedra (Benson) Stover \& Evitt. Edwards and others, 1984, pl. 2, fig. 5.

Remarks.-This small, distinctive form could perhaps represent the endocyst only. 
CHARLESDOWNIEA COLEOTHRYPTA (WILLIAMS \& DOWNIE 1966) LENTIN \& VOZZHENNIKOVA 1989

CHARLESDOWNIEA VARIABILIS (BUJAK 1980) LENTIN \& VOZZHENNIKOVA 1989

Plate 5, figure 11

Remarks.-The species name is used in the broad sense.

\section{DEFLANDREA DELINEATA COOKSON \& EISENACK 1965}

Plate 5, figure 5

Deflandrea cf. D. dartmooria Cookson \& Eisenack 1965. Edwards and others, 1984, pl. 1, fig. 7.

Deflandrea cf. D. dartmooria of Edwards and others (1984).

Edwards, 1989, pl. 1, fig. 6.

Remarks.-This form lacks the broad shoulders characteristic of Cerodinium dartmoorium (Cookson \& Eisenack 1965) Lentin \& Williams 1987.

\section{DEFLANDREA PHOSPHORITICA EISENACK 1938}

Plate 5, figure 9

DEFLANDREA N. SP. AFF. D. TRUNCATA STOVER

Plate 5, figure 8

Remarks. - The specimen shown in plate 5 , figure 8 is a rather large, circumcavate form with a granulate endocyst. This form is relatively rare in the Georgia cores studied, but it may be stratigraphically important.

\section{DEFLANDREA CF. D. DIEBELII ALBERTI OF DRUGG (1967)}

Plate 5, figure 6

Deflandrea cf. D. diebelii Alberti 1959. Drugg, 1967, p. 1617, pl. 2, fig. 6 .

Deflandrea sp. cf. D. diebelii sensu Drugg 1967. Edwards, 1980, pl. 9, fig. 4.

Cerodinium speciosum (Alberti 1959) Lentin \& Williams 1987. Kurita and McIntyre, 1995, pl. 1, fig. 1.

Remarks.-The periphragm is almost smooth (lacking striations or spinules).

\section{DRACODINIUM VARIELONGITUDUM (WILLIAMS \& DOWNIE 1966) COSTA \& DOWNIE 1979 \\ Plate 5, figure 7}

\section{ISABELIDINIUM VIBORGENSE SENSU KURITA} AND MCINTYRE (1995)

Plate 5, figure 2

Peridiniacean cyst sp. C. Edwards, 1980, pl. 9, fig. 11. Peridiniacean cyst sp. C of Edwards (1980). Edwards, 1989, pl. 1 , fig. 12 .

Isabelidinium viborgense Heilmann-Clausen 1985. Kurita and McIntyre, 1995, p. 131, pl. 1, figs. 9, 10.
Remarks. - The specimens in the Georgia cores, like the ones described by Kurita and McIntyre (1995), lack the additional openings on the pericyst that are found in the type material of Heilmann-Clausen (1985).

\section{LEJEUNECYSTA ARTZNER \& DÖRHÖFER 1978 SPP.}

Remarks.-Various species of the genus are included.

\section{LENTINIA SERRATA BUJAK 1980}

Plate 5, figure 12

\section{PALAEOCYSTODINIUM GOLZOWENSE ALBERTI 1961 PALAEOCYSTODINIUM ALBERTI 1961 SPP.}

Remarks.-Specimens of the genus Palaeocystodinium Alberti in the Georgia cores were not assigned to species if the endocyst was clearly wider than the endocyst in specimens assigned to Palaeocystodinium golzowense Alberti.

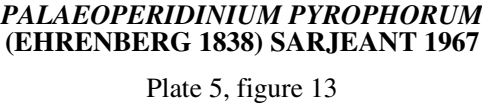

\section{PHELODINIUM SP. OF EDWARDS (1989)}

Plate 5, figure 10

Phelodinium sp. Edwards, 1989, pl. 1, fig. 9.

Phelodinium magnificum sensu lato, Edwards, 1996, pl. 1, fig. 12.

Remarks.-Phelodinium sp. of Edwards (1989) has an elongated outline and straight sides on the epicyst; that is, the epicystal shape is neither convex nor concave in the terminology of Bujak and Davies (1983). This morphotype is restricted to the upper Paleocene in Virginia (Edwards, 1989, 1996) and the Georgia cores.

\section{PHELODINIUM STOVER \& EVITT 1978 SPP.}

Plate 5, figure 14

Remarks.-Specimens from the Georgia cores assigned to Phelodinium Stover \& Evitt spp. are of miscellaneous forms, probably several different species, that broadly are similar to Phelodinium magnificum (Stanley) Stover \& Evitt sensu stricto.

\section{PHTHANOPERIDINIUM COMATUM (MORGENROTH 1966) EISENACK \& KJELLSTROM 1972 \\ Plate 5, figure 15}

\section{PHTHANOPERIDINIUM ECHINATUM EATON 1976}

Plate 5, figures 16,17

PSEUDORHOMBODINIUM LISBONENSE WRENN 1996 Plate 6, figure 1

\section{RHOMBODINIUM DRACO GOCHT 1955}

Plate 6, figure 2 


\section{RHOMBODINIUM PERFORATUM (JAN DU CHÊNE \& CHÂTEAUNEUF 1975) LENTIN \& WILLIAMS 1977 \\ Plate 6, figure 3}

SELENOPEMPHIX NEPHROIDES BENEDEK 1972

Plate 5, figure 18

SELENOPEMPHIX BENEDEK 1972 SPP.

Plate 6, figure 4

Remarks.-Various species of the genus were seen.

SENEGALINIUM MICROGRANULATUM (STANLEY 1965) STOVER \& EVITT 1978

Plate 6, figure 5

Remarks.-This species name is used in the broad sense.

\section{SPINIDINIUM DENSISPINATUM STANLEY 1965}

Plate 6, figure 8

Remarks.-This species name is used in the broad sense.

SPINIDINIUM PULCHRUM (BENSON 1976)

LENTIN \& WILLIAMS 1977

Plate 6, figures 6, 10

\section{SPINIDINIUM COOKSON \& EISENACK 1962 SPP.}

Plate 6, figure 9

Remarks.-Specimens from the Georgia cores assigned to Spinidinium Cookson \& Eisenack spp. are miscellaneous forms that do not clearly fall into the endmember morphotypes of recognized species. The illustrated specimen, recovered from the upper Eocene Barnwell unit, is probably reworked.

\section{WETZELIELLA ARTICULATA EISENACK 1938}

Plate 6, figures 7, 11

Remarks.-The species name is used in the broad sense.

\section{WETZELIELLA EISENACK 1938 SPP.}

Plate 6, figure 12

Remarks.-Specimens from the Georgia cores assigned to Wetzeliella Eisenack spp. are miscellaneous forms; many of the specimens are poorly preserved.

\section{SMALL PERIDINIACEAN FORMS}

Plate 6, figures $13-16$

Remarks.-The category "small peridiniacean forms" was used for specimens in the Georgia cores that belong to miscellaneous species of the Family Peridiniaceae Ehrenberg 1831. They belong to several genera including Alterbidinium Lentin \& Williams 1985, Lentinia Bujak 1980, Senegalinium Jain \& Millepied 1973, and Spinidinium
Cookson \& Eisenack 1962. The category includes poorly preserved specimens and specimens that do not fall into the endmember morphotypes of recognized species.

\section{ACRITARCHS}

\section{CYCLOPSIELLA VIETA DRUGG \& LOEBLICH 1967}

Plate 6, figure 17

\section{XENIKOON AUSTRALIS SENSU BENSON (1976)}

Plate 6, figure 18

Xenikoon australis Cookson \& Eisenack. Benson, 1976, p. 28, pl. 14, fig. 11.

Xenikoon australis Cookson \& Eisenack. Edwards and others, 1984, pl. 1, fig. 6 .

Incertae sedis 1 . Heilmann-Clausen, 1985 , p. 26, text-fig. 11; pl. 15, figs. 7-10.

Xenikoon australis sensu Edwards and others, 1984. Edwards, 1989, pl. 1, fig. 4 .

Remarks.-As Heilmann-Clausen (1985) pointed out, this form lacks tabulation and an observable archeopyle.

\section{REFERENCES CITED}

Benson, D.G., 1976, Dinoflagellate taxonomy and biostratigraphy at the Cretaceous-Tertiary boundary, Round Bay, Maryland: Tulane Studies in Geology and Paleontology, v. 12, no. 4, p. 169-233, pls. 1-15.

Berggren, W.A., Kent, D.V., Swisher, C.C., III, and Aubry, M.-P., 1995, A revised Cenozoic geochronology and chronostratigraphy, in Berggren, W.A., Kent, D.V., Aubry, M.-P., and Hardenbol, Jan, eds., Geochronology, time scales and global stratigraphic correlation: SEPM (Society for Sedimentary Geology) Special Publication 54, p. 129-212.

Bujak, J.P., and Davies, E.H., 1983, Modern and fossil Peridiniineae: American Association of Stratigraphic Palynologists Contribution Series 13, 203 p., 12 pls.

Clarke, J.S., Falls, W.F., Edwards, L.E., [Bukry, David,] Frederiksen, N.O., Bybell, L.M., Gibson, T.G., Gohn, G.S., and Fleming, Farley, 1996, Hydrogeologic data and aquifer interconnection in a multi-aquifer system in coastal plain sediments near Millhaven, Screven County, Georgia, 1991-95: Georgia Geologic Survey Information Circular 99, 43 p., 1 pl. in pocket.

Clarke, J.S., Falls, W.F., Edwards, L.E., Frederiksen, N.O., Bybell, L.M., Gibson, T.G., and Litwin, R.J., 1994 [1995], Geologic, hydrologic and water-quality data for a multi-aquifer system in coastal plain sediments near Millers Pond, Burke County, Georgia, 1992-93: Georgia Geologic Survey Information Circular 96, 34 p., 1 pl. in pocket.

Damassa, S.P., Goodman, D.K., Kidson, E.J., and Williams, G.L., 1990, Correlation of Paleogene dinoflagellate assemblages to standard nannofossil zonation in North Atlantic DSDP sites: Review of Palaeobotany and Palynology, v. 65, p. 331-339. 
Drugg, W.S., 1967, Palynology of the upper Moreno Formation (Late Cretaceous-Paleocene), Escarpado Canyon, California: Palaeontographica, ser. B, v. 120, p. 1-71.

1970, Some new genera, species, and combinations of phytoplankton from the lower Tertiary of the Gulf Coast, U.S.A.: Proceedings of the North American Paleontological Convention, Chicago, 1969, part G, p. 809-843.

Drugg, W.S., and Loeblich, A.R., Jr., 1967, Some Eocene and Oligocene phytoplankton from the Gulf Coast, U.S.A.: Tulane Studies in Geology, v. 5, p. 181-194, pls. 1-3.

Drugg, W.S., and Stover, L.E., 1975, Stratigraphic range charts, selected Cenozoic dinoflagellates, in Evitt, W.R., ed., Proceedings of a forum on dinoflagellates held at Anaheim, California, October 16, 1973: American Association of Stratigraphic Palynologists Contributions Series 4, p. 73-76, pls. 1-7.

Edwards, L.E., 1977, Range charts as chronostratigraphic hypotheses, with applications to Tertiary dinoflagellates: University of California, Riverside, unpub. dissertation, $188 \mathrm{p}$.

1980, Dinoflagellate biostratigraphy: A first look, in Reinhardt, Juergen, and Gibson, T.G., Upper Cretaceous and lower Tertiary geology of the Chattahoochee River Valley, western Georgia and eastern Alabama, in Frey, R.W., ed., Excursions in southeastern geology, v. 2: Geological Society of America Annual Meeting (93d), Atlanta, 1980, Field Trip Guidebooks, p. 424-427, pl. 9.

1982, Biostratigraphically important species of Pentadinium Gerlach, 1961, and a likely ancestor, Hafniasphaera goodmanii n. sp., from the Eocene of the Atlantic and Gulf Coastal Plains: Palynology, v. 6, p. 105-117.

1984, Dinocysts of the Tertiary Piney Point and Old Church Formations, Pamunkey River area, Virginia, in Ward, L.W., and Krafft, Kathleen, eds., Stratigraphy and paleontology of the outcropping Tertiary beds in the Pamunkey River region, central Virginia Coastal Plain-Guidebook for Atlantic Coastal Plain Geological Association 1984 field trip: Atlantic Coastal Plain Geological Association, p. 124-134, pls. $1-4$.

1989, Dinoflagellate cysts from the lower Tertiary formations, Haynesville cores, Richmond County, Virginia, chap. C of Mixon, R.B., ed., Geology and paleontology of the Haynesville cores-Northeastern Virginia coastal plain: U.S. Geological Survey Professional Paper 1489, p. C1-C12, pls. $1-5$.

1992, Dinocysts from the lower Tertiary units in the Savannah River area, South Carolina and Georgia, in Zullo, V.A., Harris, W.B., and Price, Van, eds., Savannah River region; Transition between the Gulf and Atlantic Coastal Plains: Proceedings of the Second Bald Head Island Conference on Coastal Plains Geology, Hilton Head Island, November 6-11, 1990, p. 97-99.

1996, Graphic correlation of the Marlboro Clay and Nanjemoy Formation (uppermost Paleocene and lower Eocene) of Virginia and Maryland, in Jansonius, J., and McGregor, D.C., eds., Palynology; principles and applications, v. 3: Salt Lake City, American Association of Stratigraphic Palynologists Foundation, p. 989-999.

Edwards, L.E., Goodman, D.K., and Witmer, R.J., 1984, Lower Tertiary (Pamunkey Group) dinoflagellate biostratigraphy, Potomac River area, Virginia and Maryland, in Frederiksen,
N.O., and Krafft, Kathleen, eds., Cretaceous and Tertiary stratigraphy, paleontology, and structure, southwestern Maryland, and northeastern Virginia: American Association of Stratigraphic Palynologists Field Trip Volume and Guidebook, p. 137-152, pls. 1-4.

Fensome, R.A., Taylor, F.J.R., Norris, G., Sarjeant, W.A.S., Wharton, D.I., and Williams, G.L., 1993, A classification of living and fossil dinoflagellates: New York, Micropaleontology Press, Special Publication 7, 351 p.

Firth, J.V., 1987, Dinoflagellate biostratigraphy of the Maastrichtian to Danian interval in the U.S. Geological Survey Albany core, Georgia, U.S.A.: Palynology, v. 11, p. 199-216, pls. 13.

1996, Upper middle Eocene to Oligocene dinoflagellate biostratigraphy and assemblage variations in Hole 913B, Greenland Sea, in Thiede, Jörn, Myhre, A.M., Firth, J.V., Johnson, G.L., and Ruddiman, W.F., eds., Proceedings of the Ocean Drilling Program, Scientific Results, v. 151, p. 203242.

Heilmann-Clausen, Claus, 1985, Dinoflagellate stratigraphy of the uppermost Danian to Ypresian in the Viborg 1 borehole, central Jylland, Denmark: Danmarks Geologiske Undersøgelse, Serie A, no. 7, p. 1-69, pls. 1-15.

Kurita, Hiroshi, and McIntyre, D.J., 1995, Paleocene dinoflagellates from the Turtle Mountain Formation, southwestern Manitoba, Canada: Palynology, v. 19, p. 119-136, pls. 1, 2.

Leeth, D.C., Falls, W.F., Edwards, L.E., Frederiksen, N.O., and Fleming, R.F., 1996, Geologic, hydrologic, and water-chemistry data for a multi-aquifer system in coastal plain sediments near Girard, Burke County, Georgia, 1992-95: Georgia Geologic Survey Information Circular 100, 26 p, 1 pl.

Lucas-Clark, Joyce, 1992, Some characteristic fossil dinoflagellate cysts of Eocene strata, Savannah River Site, South Carolina, in Fallaw, W.C., and Price, Van, eds., Geological investigations of the central Savannah River area, South Carolina and Georgia (Carolina Geological Society field trip guidebook, November 13-15, 1992): U.S. Department of Energy and South Carolina Geological Survey, p. CGS-92-B.VII.1B.VII.6.

Morgenroth, Peter, 1966, Mikrofossilien uns Konkretionen des nordwesteuropäischen Untereozäns: Palaeontographica, ser. B, v. 119, p. 1-53, pls. 1-11.

Prowell, D.C., Christopher, R.A., Edwards, L.E., Bybell, L.M., and Gill, H.E., 1985 [1986], Geologic section of the updip coastal plain from central Georgia to western South Carolina: U.S. Geological Survey Miscellaneous Field Studies Map MF1737, 10-p. text, 1 sheet.

Prowell, D.C., Edwards, L.E., and Frederiksen, N.O., 1985 [1986], The Ellenton Formation in South Carolina-A revised age designation from Cretaceous to Paleocene, in Stratigraphic notes, 1984: U.S. Geological Survey Bulletin 1605-A, p. A63-A69.

Sarjeant, W.A.S., 1981, A restudy of some dinoflagellate cyst holotypes in the University of Kiel collections-II. The Eocene holotypes of Barbara Klumpp (1953); with a revision of the genus Cordosphaeridium: Meyniana, v. 33, p. 97-132.

Stover, L.E., and Hardenbol, Jan, 1993 [1994], Dinoflagellates and depositional sequences in the lower Oligocene (Rupelian) Boom Clay Formation, Belgium: Bulletin de la Société belge de Géologie, v. 102, nos. 1-2, p. 5-77, pls. 1-13. 
Williams, G.L., Lentin, J.K., and Fensome, R.A., 1998, The Lentin and Williams index of fossil dinoflagellates-1998 edition: American Association of Stratigraphic Palynologists Contribution Series 34, $817 \mathrm{p}$.
Wrenn, J.H., 1996, Pseudorhombodinium lisbonense gen. et sp. nov., a new dinoflagellate fossil from the Lisbon Formation (middle Eocene), Little Stave Creek, Alabama: Palynology, v. 20, p. 209-219. 